\title{
INTERPRETING DEVELOPED COUNTRIES' FOREIGN DIRECT INVESTMENT
}

\author{
Robert E. Lipsey \\ Working Paper 7810 \\ http://www.nber.org/papers/w7810
}

\author{
NATIONAL BUREAU OF ECONOMIC RESEARCH \\ 1050 Massachusetts Avenue \\ Cambridge, MA 02138 \\ July 2000
}

An earlier version of this paper was presented at the Deutsche Bundesbank conference on "Investing Today for the World of Tomorrow," 28-29 April 2000. The current version will be included in the volume of conference papers, to be published by Springer Verlag. I am indebted to my discussants, Michael P. Devereux, of the University of Warwick and John Hawkins, of the Bank for International Settlements, and to other participants, for stimulating suggestions, some of which helped in my revision and some of which will inform my future research. Li Xu provided vital computer and research assistance for the chapter. The views expressed here are the author's and do not necessarily reflect those of the National Bureau of Economic Research.

(C) 2000 by Robert E. Lipsey. All rights reserved. Short sections of text, not to exceed two paragraphs, may be quoted without explicit permission provided that full credit, including $\mathbb{C}$ notice, is given to the source. 
Interpreting Developed Countries' Foreign Direct Investment

Robert E. Lipsey

NBER Working Paper No. 7810

July 2000

JEL No. F23

\begin{abstract}
$\underline{\text { ABSTRACT }}$
Inward and outward direct investment (FDI) stocks and flows tend to go together, across countries and over time. The countries that invest extensively abroad are usually also large recipients of FDI.

There is little evidence that flows of FDI are a major influence on capital formation. That lack of effects suggests that financing capital formation is not a primary role of FDI.

FDI transfers the ownership of existing productive assets from one set of owners to others willing to pay more for them, possibly from less efficient to more efficient owners. One fact that suggests this function is that outward U.S. FDI production and outward minus inward production tends to be concentrated in industries of U. S. comparative advantage. It is not in industries of U.S. comparative disadvantage, as might be expected if FDI were primarily a method of relocating production to more suitable locations. Within individual broad industry groups, U.S. FDI tends to move to countries with comparative disadvantages in trade relative to the United States in machinery industries. In resource-intensive industries, however, it moves to countries with comparative advantages in trade relative to the United States. The difference suggests that company comparative advantages dominate investment in machinery, but country comparative advantages dominate in resource-intensive industries.

If FDI is transferring assets and production from less efficient to more efficient owners and managers, inward FDI can be viewed in the recipient countries as freeing capital that had been frozen in industries that the owners would prefer to leave. It permits the former owners to allocate their capital in more desirable and profitable ways. Outward FDI permits a home country's firms to optimally exploit their skills and comparative advantages, perhaps lost to the home countries, but retained by the country's firms.
\end{abstract}

Robert E. Lipsey

National Bureau of Economic Research

365 Fifth Avenue, $5^{\text {th }}$ Floor

New York, NY 10016-4309

(212) 817-7961

rlipsey@gc.cuny.edu 
Much of the analysis of and research on foreign direct investment (FDI) is based on the idea that it is simply one of the many possible forms that international capital movements can take, creating production in lower cost locations or shifting production to them. An advantage of this view is that there is a theory of international capital flows, involving differences among locations in the abundance of and returns to capital. Applied to direct investment, this type of theory underlies the expectation, or fear, that outward FDI is likely to be a substitute for exports. Over the years, studies of various aspects of FDI have turned up characteristics that suggest that this view missed much that was important about direct investment. There is, for example, the fact that most direct investment takes place among developed countries, where the differences in rates of return and capital abundance are not very great. Also, it is typically found that foreign production and exports from home, for both firms and countries, are positively related to each other, both geographically and over time.

This chapter suggests a different view of how FDI among developed countries, which is the majority of FDI, affects the home and host countries involved. That is not to say that net flows of direct investment capital from developed to developing countries or from richer to poorer countries are not taking place. The net flow of direct investment has been in this direction, we might say, downhill. Developing Asia and Latin America have been net recipients and Japan and Europe have been net investors in all five-year periods since 1970. Only the United States has flipped from one side to the other (Lipsey, 1999b, Table 6A-4). But much more than that downward flow is taking place, especially among developed countries, and I focus here on other issues. One is the large inward and outward gross flows that occur simultaneously, and the inward and outward stocks in place at any time. These disappear in examinations of net flows and stocks. The second is the industrial composition of direct investment in and out of a country and the measurement of this investment and its composition by the extent of real activity rather than by financial flows and stocks.

I have always preferred to analyze what I think of as measures of direct investment activity, production, employment, capital expenditures, and capital stocks, rather than balance- of- payments measures of flows and stocks. One reason for this preference is that the balance- of-payments measures 
often do not represent well what I consider the important feature of direct investment: production owned and operated across international borders. They do include all kinds of financial flows and stocks that have little to do with production and are more akin to portfolio investment. An example is the large negative U.S. direct investment stock in the Netherlands Antilles that reached negative $\$ 25$ billion in 1984, more than 10 per cent of total U.S. direct investment abroad (Lipsey, 1998, Table 8.A.1). The whole operation involved little or no production; it was a tax-induced transformation of what was essentially portfolio borrowing into nominal direct investment transactions.

This objection to the balance- of- payments data would hold even if the data were accurate. However, it is clear that they are not. Each new volume of the IMF Balance of Payments Yearbook shows that there are still large discrepancies between reported inward and outward flows, with \$26 billion of outward flows missing in 1998 (IMF, 1999, Table B-24).

The problems with using balance of payments data on FDI as a proxy for production in FDI operations can be illustrated by a comparison of the country distributions of the U.S. FDI stock, and changes in it, with those of production. At any particular time, the stock is a reasonable proxy for output, as represented by gross product of majority-owned affiliates. In 1977, 1982, 1989, and 1994, the R-sq was above .8 in every year. But changes in stocks give virtually no guidance to changes in the location of production. In the three periods, 1977-1982, 1982-1989, and 1989-1994, the correlation between changes in output in a country and changes in stocks was not even statistically significant in two. Only in the last period was the relationship significant, and even then the R-sq was below .4.

A paper by Thomas Jost (1997) includes some comparisons for Germany vis-a vis 18 OECD countries combined that show that over the period 1984-1994 German balance- of- payments statistics reported direct investment outflows to these countries more than a third larger than these countries' reported inflows. Of course, the differences were much larger in some individual years (p. 6). Comparisons with seven individual countries for the same period showed differences even in the direction of the flow in five cases. 
The balance- of- payments data do have one advantage. They are available for many countries over many years, while direct investment activity data are available for only a few countries. As long as that remains true, the balance- of- payments data will be used, and are used here, whenever approximations to world totals or observations for many countries are needed.

This chapter deals only with the developed countries, although some of the flows and stocks of FDI examined include those to and from developing countries. We define developed countries here as the members of the OECD with the exception of Korea, Mexico, and the formerly planned economies. However, several other OECD countries, such as Greece, Iceland, Ireland, and Turkey, are omitted from some calculations because data on FDI are not available or available for only limited periods.

\section{$\underline{\text { Relations between Inward and Outward FDI }}$}

If FDI flows represented mainly responses to differences among countries in the scarcity and price of capital, countries would tend to be mainly investors or mainly recipients of FDI capital. A country that was capital-abundant would be a large investor and a small recipient while a capital-poor country would be a large recipient and a small investor. The level of outflows and the level of inflows, given the size of the country, would be negatively related.

This does not appear to be the case. Across the developed countries included here, and over the longest time spans available, the larger investors, relative to their GDPs, tend also to be the larger recipients of FDI (Table 1, Eq. 1-1). That relationship is not statistically significant by conventional standards, but there is no sign of the opposite relationship, of large investors, relative to the size of their countries, being small recipients, and vice versa.

One might imagine that the coexistence of outward and inward stocks arose from an alternation between outward and inward flows, depending on economic conditions relative to partner countries. If FDI flows were mainly responses to differences between countries in current economic conditions, inflows would rise in prosperous times and outflows would fall. In recessions, inflows would fall and outflows would rise. For any one country, the relationship between the two flows would be negative. In 
fact, there is a strong positive relationship between the inflows and the outflows in a year for a given country, as was pointed out in Lipsey (1999b) for an assortment of developed and developing countries.

The same relationship over time can be seen for the developed countries covered in this chapter, from 1970 through 1995, in equation 1- 2 in Table 1. To some extent, that positive relationship must reflect growth, but if the growth effect is removed by taking ratios of FDI flows to GDP, the strong positive relationship remains, as can be seen in equation $1-3$.

The relationship between inflows and outflows of FDI relative to total output over time is positive and significant in 13 of the 19 individual countries, and there are no significant negative coefficients. In other words, the short-term economic developments that encourage inward flows of FDI also promote outward flows.

\section{Determinants of Inward FDI}

What determines the amount of FDI a country receives? More or less standard candidates are the country's size, measured here by its nominal GDP, translated into US dollars by exchange rates, its rate of growth, measured by growth in per capita GDP, and its income level, measured by per capita real GDP. Nominal GDP is used as the size indicator only because it is the denominator for various ratios in which nominal FDI flows or stocks, for which we have no obvious deflator across countries, are the numerators.

Since the inflow of FDI during a period may affect these variables, we date the independent variables as of the beginning of each period, in the case of level variables, or over the preceding period, in the case of flow variables. Five- year intervals are the basis here for explaining stocks of FDI and medium-term changes in flows. We interpret annual data as reflecting short-term, possibly cyclical, effects more closely.

The independent variables in all the equations are the country's size, as measured by nominal GDP, and the level of real per capita income, both at the beginning of the period, and its growth in per capita real income during the preceding period. Later equations add the ratio of fixed capital formation to GDP and the ratio of trade (exports plus imports) to GDP, as well as country dummy variables and lagged values of the dependent variables. 
The equations in Table 2 attempt to explain a country's stock of inward FDI relative to GDP at the end of each five-year period. In equation 2-1, the coefficient for country size is negative and that for the real income level is positive. The equation becomes insignificant if the United States and Japan are omitted from the data set although the coefficient for per capita income does not change much (Equation 2-3). If we instead add country dummy variables to this equation, with the United States as the omitted country, the coefficient for country size becomes insignificant, but the coefficient for the real income level and its t-value are hardly changed (Equation 2-2). The significant country dummies are all positive, and the countries that appear to have large amounts of inward FDI for their income levels are Australia, Belgium-Luxembourg, Canada, The Netherlands, and the UK.

The country's past ratio of fixed capital formation to GDP adds to the explanation; it appears to be a repellent to inward FDI rather than an attraction (Equation 2-4), as if a high level of investment in one period may have preempted what would otherwise have been opportunities for foreign investors. However, a measure of openness of the economy to trade, the ratio of the sum of exports and imports to GDP, is positively related to the inward FDI stock (Equation 2-5). The country's past ratio of inward FDI stock to GDP adds greatly to the explanation of the current ratio (Equation 2-6). It provides as much of an explanation as country dummy variables (and is equally unenlightening as to causation), but the additional degree of explanation is at the expense of the income level variable, rather than of the growth rate measure.

Two other variables thought to affect the attractiveness of a country to FDI are the tax rate on companies and the average nominal wage level, both estimated crudely from U.S. outward investment surveys. These were tried as alternatives to the lagged capital formation and trade ratios, but the results were inferior and are not shown here.

The equations in Table 3 attempt to explain the inflow of FDI relative to GDP over 5-year periods. As in the stock equations, country size and lagged investment ratios are negatively related to FDI inflows, with the coefficients for the investment ratios more consistently significant (Equations 3-4 to 3-6). Per capita real income and openness are positively related to FDI inflows, and coefficients for past growth 
rates were not statistically significant. If the lagged inward investment flow is added (Equation 3-6), it a strong positive influence, and weakens that of country size and openness. Thus there are major persistent determinants of inward FDI that are not explained by the variables included in these equations, but are picked up by country dummies (Equation 3-2) or about equally well by the lagged investment stock variable. Substituting tax rates and wage rates for the capital formation and trade ratios provides no significant coefficients and causes the explanation to deteriorate (not shown).

Equations for the inflow of FDI on an annual basis (Table 4) differ from those for the stock and for 5year periods in one major respect: the coefficient for lagged growth in per capita real income is consistently significant, and it is positive. Real per capita income levels and trade ratios remain positive influences and country size and the lagged capital formation ratio negative ones. Thus a high rate of growth in real per capita income is a factor attracting inward FDI over short periods, but not over longer ones. If we add a variable for lagged inward FDI flow (Equation 4-6), it shows that a strong serial correlation characterizes these flows. The coefficients for lagged growth, per capita real income, and the investment ratio are still significant, reflecting effects over time rather than only differences across countries.

Without including country dummy variables or past values of the dependent variables in the equations, we explain, at most, less than 20 per cent of the variance in inward stocks of FDI relative to GDP, a little more of that in flows over five-year periods, and less of that in annual flows. In general, large country size and past high levels of capital formation are negatively related to inward FDI stocks and flows. And high per capita real income and high trade ratios are positively related. Past growth rates of per capita GDP are a significant and positive influence only on annual inflows of FDI.

Some of these influences fade when country dummy variables or past levels of dependent variables are introduced. The implication is that the influences that disappear are mainly effects across countries rather than over time for a given country. The positive influence of real income levels and the negative influence of past capital formation rates remain significant for FDI inflows. 


\section{$\underline{\text { Determinants of Outward FDI }}$}

If the flow of direct investment reflected mainly the relative scarcity of and returns on capital in different countries, we might expect to find that the determinants of outward FDI were the same economic characteristics as those of inward FDI, but with the opposite signs. For the stock of outward FDI, relative to GDP, that is clearly not the case (Table 5). Country size (reflecting the United States and Japan) and lagged capital formation, significantly, are negatively related to the outward stock (Equations 5-1 to 5-4). Real per capita income and openness are positively related (Equation 5-5). For all these factors, the direction of the relationship is the same as for inward FDI (Table 2). As was true for the inward stock, the large holders of FDI assets in one period are the large holders in the next period. Every combination of variables used here to explain the inward FDI stock explains the outward stock better.

Much the same story holds for outward flows over five- year periods. Country size is negatively related to outward FDI flows, not only because of the United States and Japan. The past capital formation ratio is also negatively related to it (Equation 6-4), as if domestic capital formation were competing with foreign uses of capital funds. That result fits with the Stevens and Lipsey (1992) finding that capital expenditures abroad and at home were competitors for finance within the firm. High per capita income and openness are positively related to outward FDI, and the outward flows are serially correlated. As with the stocks, every combination of variables explains outward flows better than inward flows (Table 3)

Annual outward flows of FDI are associated with the same influences, except that lagged growth in per capita real income is significant for the annual outflows (Table 7), as it is for the annual inflows (Table 4). The finding that rapid growth attracts inward investment the next year seems more obvious intuitively than the finding that it also propels outward investment. Country size and the lagged capital formation ratio are negatively related to outward flows. The fact that higher capital formation in one year is associated with lower outflows of FDI the next year could be plausibly interpreted as reflecting cyclical fluctuations in the relative attractiveness of the domestic and foreign economies. That interpretation would be more convincing if the capital formation ratio did not have the same sign in the inward investment equation. 
As in the other equations, higher per capita income and greater openness are positively related to outward direct investment flows, and the degree of explanation of the flows is larger for outflows than for inflows. The only exception to that is that lagged outward investment does not add as much to the explanation of the flows as lagged inward investment.

\section{$\underline{\text { Determinants of Net FDI Stocks and Flows }}$}

If we are interested in the implications of direct investment for the supply of capital, the net flows and stocks might be of more interest than the gross flows in and out of each country. The variables considered so far with respect to the gross stocks and flows do nothing to explain the net stocks (Table 8). The net stocks are "explained" by country dummy variables (Equation 8-2) or simply by the net inward stocks, relative to GDP, of five years earlier (Equation 8-6). The coefficients for the other variables that were significantly related to the gross stocks, such as real per capita income, the capital formation ratio in the previous period, and the trade ratio in the previous period, are all insignificant in the equations for net stocks. The effects of these variables on the inward and outward sides of the account cancel each other out. As a consequence, little of the variation in net stocks is explained by the equations. Only the unexplained long-term variation across countries remains. The persistence of the attractiveness of countries as hosts to FDI outweighs that of countries as sources for FDI.

A similar story can be told about net inflows of direct investment over five-year periods. None of the variables that were significant for gross inward or inward flows has an impact on the net inflows, although real GDP per capita comes closest (Table 9). There is some faint tendency for the richer countries to be net suppliers of FDI, but that is an effect across countries that disappears when the lagged net inward flow is included in the equation. The major net recipients of FDI five years earlier are the major recipients at each date.

In the annual regressions, the lagged growth plays no significant role, indicating that the annual movements in gross and net flows offset each other (Table 10). The lagged level of real income does have a generally significant negative coefficient, indicating a stronger impact on outflows than on 
inflows, but the country dummies (Equation 10-2) or lagged net FDI positions (Equation 10-6) are still the variables with the strongest relation to net investment on an annual basis.

\section{Summary: Explaining FDI Stocks and Flows}

What, if anything, do these regressions tell us, or suggest to us, about what influences FDI? They represent a simple-minded, or perhaps naïve, attempt to find keys to that question, but I think they point to some characteristics of FDI. One is that inward and outward stocks and flows of FDI seem to go together, both across countries and over time. Another is that there is a great deal of persistence in a country's position, particularly as a recipient of FDI, but also as an investor. Some of this persistence, but only a small part, can be explained by persistent country characteristics, such as size, real income per capita, and openness to trade. Most of it eludes the variables included here.

On the whole, large countries and those with past high capital formation relative to their GDP, invest and receive less FDI than others, relative to their size. Richer countries and more open ones both invest and receive more FDI relative to their size. And with all of these influences, the gross stocks and flows of FDI, while not explained well, are better explained than the net flows.

\section{$\underline{\text { FDI Flows and Capital Formation }}$}

One of the reasons for interest in FDI flows is that they are a possible source of financing for a country's capital formation. There have been some studies in the past on this relationship, particularly for Canada, concluding that, over time, there was a strong relationship between inflows of FDI and capital formation. An early study by Lubitz (1966), based on quarterly data, found in some regressions that “...\$1.00 of direct investment 'led' to $\$ 3.00$ of capital formation...” (pp.97-98). A later study by Van Loo (1977), based on annual data, found a positive direct on Canadian capital formation greater than the inflow of FDI. However, that was partly offset by various indirect effects through Canadian exports, imports, and consumption, so that the net impact on capital formation was only a little over half the amount of the inward flow of FDI.

Even if such a relationship were demonstrated, the impact on a host country might be small if FDI flows were a minor part of the country's capital formation. The average ratios of inward FDI flows to 
gross fixed capital formation (GFCF) over the available years for each country from 1970 through 1995 are shown in Table 11. They range from as high as 15 to 17 per of GFCF for Benelux and New Zealand, but the rest are below 10 per cent, and most are under 5 per cent. Thus the effect of FDI inflows might be difficult to distinguish among the many factors influencing capital formation.

Despite the smallness of the direct investment inflows relative to GFCF, they could have some effect on capital formation. Table 12 presents some evidence on the relation to total capital formation ratios (GFCF/GDP) over 5-year periods. The first four equations do not include a lagged dependent variable, while the second four do. In these first four equations, lagged growth in per capita real GDP is a consistently positive influence on current capital formation. When we relate the capital formation ratios to the inward FDI flow ratios of the preceding 5-year period, there is a negative, but not quite significant, coefficient (Equation 12-1), instead of the positive one we would have expected if FDI inflows were providing financing for capital formation. For outward FDI flows, we would expect a negative coefficient if outward FDI were reducing the funds available for financing capital formation. We do find it, it is statistically significant at the 5 per cent level, and it explains more of capital formation than inward flows (Equation 12-2). Capital formation is lower in the current period, relative to GDP, if outflows of FDI were higher in the previous five years. This apparent effect of FDI flows does not seem to stem from their role as a source of aggregate financing for the economy. Net flows of FDI have no significant effect on the capital formation ratios of the following 5-year period, as we would expect if they were mainly sources of finance (Equation 12-3).

If we add lagged capital formation ratios to these equations, they explain most of the variance in current ratios. The acceleration effect disappears; past per capita growth rates do not appear to have any effect on capital formation (Equations 12-5 to 12-8). Coefficients for both inward and outward flows are negative in separate equations, and fairly similar in size, but only that for outflows is significant. When they are entered together, however, coefficients for them are both negative, but neither is significant. The net flow of FDI does not appear to have any significant effect on aggregate capital formation ratios. 
Annual changes in capital formation can be related to the same variables at an individual country level. The story is not much different. In most cases, neither the inward FDI flow nor the outward flow has a significant effect on the following year's capital formation. The ratio of inward FDI flow to GDP is significantly related to the next year's capital formation ratio in only eight countries, and for six of them, the relationship is negative. It is, however, positive for Canada, as in the earlier studies referred to above. The significant coefficients for the outward FDI flow ratio are positive in only one case and negative in three, and those for the net inflow ratio are similarly mixed, a little more often negative than positive. Thus, even on an annual basis, FDI flows in or out of a country do not appear to significantly influence the country's capital formation ratio.

One might imagine that the effects of flows of FDI would be concentrated in the private, and especially in the corporate, sector. They presumably enter or come from the corporate sector, except in the case of privatizations, where it is the government sector that receives the capital inflows. Table 13 describes some equations linking FDI, and other variables, to public capital formation.

A consistent feature of the public capital formation equations is that lagged per capita GDP growth is a positive and significant influence on current public capital formation ratios. That is true even when the lagged public capital formation ratio is included as a variable. Rapid economic growth produces a rise in share of public capital formation in GDP, perhaps because of a rise in government revenue. The only relationship found with FDI flows is that the coefficient for lagged inward flows is always negative and sometimes statistically significant. There does not seem to be any strong reason to expect positive coefficients on inward FDI for public capital formation, since governments are not typically recipients of FDI inflows, except where privatization is taking place. In that case, governments might have been deliberately shedding capital-intensive activities that required large capital formation expenditures. They might be needed for modernization or upgrading of quality, especially if they had been neglected under government ownership. Successful privatizations to foreign investors might then have reduced government capital formation requirements. However, it is not clear that the public sector, as defined to exclude quasi-private or quasi-corporate enterprises, would have been the recipient of such investment. 
Table 14 summarizes attempts to explain corporate and quasi-corporate capital formation relative to GDP. There is no evidence of an effect of past growth, and the equations explain almost nothing if the lagged dependent variable is not included (Equations 14-1 to 14-4). The coefficients for inward FDI flows are marginally significant, but negative. If there is any impact of inward FDI, it is not as a way of financing local capital formation. The equations including the lagged dependent variable (Equations 145 to 14-8) explain much of the variation in capital formation ratios, mainly by past capital formation. The coefficients for gross inward and outward flows are both negative, but only that for lagged outward flow is significant.

A shorter term view of corporate and quasi-corporate capital formation is provided by Table 15 . Faster growth in per capita real income last year is significantly associated with higher capital formation, relative to GDP, this year. The coefficient for real income growth is smaller when lagged capital formation is included in the equation, but lagged real income growth remains a consistently significant variable. Inflows and net inflows of FDI are also a significant influence, always negative, but outflows never are.

Since there is no obvious reason why inflows of FDI should reduce capital formation, it seems most likely that some omitted variable is producing both the inflows and the later reductions in capital formation ratios. One could imagine that high interest rates might attract capital and discourage capital formation in the short run, but that type of effect is usually associated with short-term portfolio capital movements, rather than direct investment. A possible avenue for direct investment to respond in this way would be for affiliates, during a period of high host country borrowing costs, to substitute short-term borrowing from parents for local borrowing. This possibility would have to be examined with different types of data from those used here.

On the whole, we have explained little of changes in national capital formation ratios, except by past capital formation. While much better investment equations must exist, we find no evidence here that either inflows or outflows of FDI are crucial to determining the level of capital formation. 


\section{FDI as Changes in Firm Ownership}

To the extent that FDI flows into and out of a country offset each other, or country A's stock of FDI in country B more or less matches in size country B's stock in country A, direct investment is not acting mainly as a way of transferring capital from one country to another. What is it doing? It is shifting the ownership of particular productive assets from firms in one country to firms in another country without necessarily changing either country's capital position. Portfolio flows can be thought of as entering some broad capital market in which foreign capital is indistinguishable from domestic capital. Direct investment, as measured in the balance- of- payments accounts, may act much like portfolio investment, in the sense that the capital freed by foreign acquisitions and mergers becomes free to move to other industries or other countries. But direct investment, as measured by foreign-owned host-country production or home-country firm production abroad, is different. It is associated with a particular owner, in a particular industry, with particular skills and a particular portfolio of other productive assets. The literature that deals with this type of shuffling of assets is the industrial organization literature on corporate takeovers and mergers, rather than that on international capital flows.

There are many possible reasons for these changes of ownership or explanations for the higher value that an investing country's firms put on an asset than host country firms do. When firms in the same industry are investing in each other's home countries, the investments may reflect the contest for markets, where proximity to markets is important for market share. Home country firms already have that proximity to their home markets, but foreign firms may not, if they are not yet producing there. They are therefore willing to pay a premium for host country productive assets or whole firms with well known brand names or distribution networks.

Where investments in two directions are in different industries, there is the possibility that firms in a host country have fallen behind technologically in an industry and are pessimistic about catching up or competing with superior foreign firms. A takeover by a foreign firm then brings the superior technology to the host country and frees the host country capital tied up in that industry. That capital can then move to the industries in which the host country has technological advantages. 
There has been a great deal written about the consequences of takeovers and mergers, particularly in the United States. Some of that literature is summarized in Lichtenberg (1992), which also includes analyses of the determinants and effects of takeovers. One of these is a cross-country study of mergers and leveraged buyouts in 1988-90 that shows the proportion of firms merged or acquired during that period ranged from 19 per cent in New Zealand to 0 in the Netherlands. Of the five countries listed earlier here as having large inward FDI for their size, four are in the upper half of Lichtenberg's distribution for the frequency of takeovers and mergers.

Most of the literature on takeovers and mergers does not distinguish foreign from domestic acquirers, but does suggest the possibility of productivity gains. Lichtenberg found that the U.S. firms that merged or were acquired "...tend to be formerly healthy firms whose financial condition has deteriorated...prior to the transaction...” (p.101). In a study of changes in ownership of U.S. manufacturing plants, in the same volume, he suggests that “...ownership change is primarily a mechanism for correcting lapses of efficiency... A plant's owner is operating in a less efficient manner than an alternative parent could..." (p. 27) and “...ownership change or asset redeployment is an important mechanism for correcting lapses from efficient producer behavior. The gains realized by both target and acquiring shareholders appear to be social gains, not merely private ones" (pp. 42-43).

One reason for relating FDI to mergers and acquisitions is the fact that much of the flow of FDI is of that type, rather than "green field" investments that necessarily involve capital expenditures. Between 1990 and 1996, for example, over 80 per cent of foreign firms' outlays for FDI in the United States were for acquisitions, rather than new establishments (Fahim-Nader and Zeile, 1997). Between 1987 and 1992, approximately 95 per cent of employment in new foreign direct investments in the United States was in acquired enterprises (Feliciano and Lipsey, 1999, p.2).

Although most evidence of productivity and wage differentials between foreign-owned and domestically owned operations relates to developing countries, there is some also for the United States in recent years. These indicate a margin of about 10 per cent in favor of foreign-owned plants for both wages and labor productivity (Aitken, Harrison, and Lipsey, 1996, p. 360), a positive effect of higher 
foreign presence in an industry on industry productivity, and even a positive effect of higher foreign presence in an industry on the productivity of domestically-owned establishments (ibid, p. 362). One of the very few studies specifically of foreign takeovers, for the United Kingdom, found that, relative to firms in domestic takeovers, firms taken over by foreigners increased both productivity and wages (Conyon, Girma, Thompson, and Wright, 1999). Thus there is some evidence that suggests that foreign ownership and foreign takeovers are associated with possession of superior technology by the foreign firm.

What kind of evidence might show whether FDI was moving assets from host country owners lagging in technology to foreign firms leading in technology? A convincing test would certainly require individual firm microdata. Lacking these, we might find some clues in bilateral trade and FDI data, but making the connection requires some uncomfortable assumptions. One possible assumption is that comparative advantage relative to the world as a whole, or comparative advantage relative to another country, represents mainly technology gaps between countries rather than differences in factor abundance. Another is that technological leads or lags characterize whole industries, and not only some firms within them. Still another is that the comparative advantages of a country's firms reflect those of the home country itself, either present or past.

With these assumptions, we could identify industries of country comparative advantages in trade with technological leads of firms in those industries based in that country, and comparative disadvantages in trade with lags in technology for firms in those industries. We could then relate these leads and lags to movements of direct investment.

This use of this link here has a paradoxical aspect. It might appear that direct investment capital and production in an industry are expected to move from countries with comparative advantage in an industry to countries with a comparative disadvantage. However, that is not the implication. The implication is that ownership moves, from owners with technological or efficiency disadvantages in an industry to owners with technological or efficiency advantages. There is no necessary implication of any movement 
in the location of production or employment, although there is an implication that productivity will improve after the change of ownership.

The U.S. domestic manufacturing sector provides an example of the type of ownership change envisaged here. From 1977 to 1997, the share of U.S. manufacturing multinational parents in U.S. manufacturing output fell from 65 to 55 per cent, while the share of their majority-owned affiliates in their firms' total output rose substantially. That might appear to be a change in the distribution of manufacturing output across countries. However, over the same period, the share of foreign-owned manufacturing affiliates in U.S. manufacturing production rose from $3 \& 1 / 2$ per cent to $12 \& 1 / 2$ per cent, almost completely offsetting the decline in the U.S. parent share (Lipsey, 1999a, p. 9).

The analysis of changes in ownership should ideally be carried out between pairs of countries. However, at a detailed industry level, we can compare the United States only with the rest of the world. Trade comparative advantages are relatively available, but data on FDI in any industry detail are restricted to a few countries. Even for these countries, industry classifications are not easily matched.

Table 16 presents a rough picture, for the United States alone, of export comparative advantage in 34 manufacturing industries in 1970 and 1989, which we assume is an indicator of the technological advantages of U.S. firms. It also presents several aspects of inward and outward FDI production. These are based on the share of each industry in total value added in foreign affiliates of U.S. firms and in U.S. affiliates of foreign firms. The table shows the share of each industry in total production by foreign manufacturing affiliates in the United States in 1994 and in U.S. affiliate manufacturing production abroad in 1977 and 1994. There are also indicators of relative (U.S./foreign) FDI activity and changes in U.S. FDI activity. One is the ratio in 1994 of the industry output share in U.S. outward FDI to the industry output share in U.S. inward FDI. The second is the ratio of the industry output share in U.S. outward FDI in 1994 to that in 1977.

If technological leads were driving the movement of direct investment, and if comparative advantage represented technological leads, we would expect industries of U.S. comparative advantage to be major 
sources of outward FDI. Industries of U.S. comparative disadvantage would attract foreign FDI to the U.S.

The industries of greatest U.S. export comparative advantage in 1994 were Computer and office equipment (22), Construction, mining, etc. machinery (21), Other transportation equipment (29), mainly aircraft, and Electronic components (26). Computer and office equipment and Electronic components behaved as might be expected from this hypothesis: they were large outward investors and the ratio of outward to inward FDI production shares was high. However, there was little outward investment or overseas production in Other transportation equipment (mainly aircraft in the trade data) and relatively little in Construction and mining machinery.

Among industries of U.S. comparative disadvantage, Apparel and textiles (5), Primary ferrous metals (17), Stone, clay, and glass products (31\&32), and Other manufacturing (34) all follow the pattern of higher shares in inward FDI production than in outward FDI production. These relationships need more thorough analysis, but at first glance, at least, there seems to be some confirmation of the idea that the industry distribution of outward FDI production reflects the comparative advantages of the investing country, presumably because they are incorporated into the technological advantages of its multinationals. And inward FDI production reflects the comparative disadvantages of the host country, presumably because they represent comparative advantages of investing countries incorporated into the technological advantages of those countries' multinational firms. Foreign firms are thus producing in the United States in the industries of U.S. comparative disadvantage. That would be odd if the foreign investment reflected a movement of production to the United States by these firms, but not if the foreign-owned production represented a shift to foreign ownership in industries in which U.S. firms had lost their technological leadership.

The idea behind Table 16 is that the comparative advantage of the United States as a country in one period later becomes the comparative advantage of U.S. multinationals (MNCs), exploited through overseas production. If the multinationals are the most productive firms, or the ones that are technological leaders, it may be their comparative advantage that propels foreign direct investment. Table 
17 describes the export comparative advantages of U.S. parent firms and U.S. multinationals, including both the parents and their foreign affiliates. Their comparative advantage is measured by comparing the industry distributions of parent and affiliate manufacturing exports from all locations with that of the world as a whole, the same denominator as for Table 16. Most of the pattern of comparative advantage is similar to that of the United States, but there are differences. The MNCs and parents had greater comparative advantages than the United States as a country in Grain mill and bakery products, Soaps, Cleansers, etc., Farm and garden machinery, and particularly in Drugs, and a smaller comparative advantage in Construction and related machinery.

We can use the data of Tables 16 and 17 to relate U.S. and U.S. MNC export comparative advantage in one period to the distribution of overseas production across detailed BEA industries in a later period. The relationships are summarized in Table 18 .

In equations 18-1through 18-4, the share of an industry in U.S. MNCs' production abroad at the end of each period is related to the comparative advantage of the United States as a country at the beginning of the period. In three out of the four periods, there was a significant positive relationship, the exception being 1989-1994. Thus, U.S. comparative advantage at the beginning of a period usually went some way toward predicting the industry distribution of U.S. overseas production at the end of a period.

The 1989 U.S. country comparative advantage did not predict the composition of inward FDI production in the United States in 1994 or the ratio of outward to inward production, but the 1970 U.S. country comparative advantage did have the expected positive relationship to the 1994 outward/inward production ratio.

The U.S. MNC comparative advantages in 1989 do much better in predicting 1994 outward FDI production shares and ratios of outward to inward shares than U.S. country comparative advantages in that year. That is what would be expected if MNC comparative advantages reflected efficiency advantages. There is a problem with this interpretation, however, which is that the MNC comparative advantages may reflect past outward production shares. A corresponding calculation using parent 
comparative advantage would reduce the role of past investment on comparative advantage, but not eliminate it.

It would be preferable to examine comparative advantage and affiliate production across detailed industries bilaterally with individual countries, but the production data are not published in sufficient industry detail for most countries. Data do exist for a substantial number of countries by broad industry groups, rather than individual industries. The groups are too broad to be useful for analyzing the industry composition of FDI production but they may shed some light on the choice of locations within industries, although the broadness of the industry categories will blur the results. A predominant role for the exploitation of firm technological advantages would suggest that U.S. FDI production moved toward countries of low comparative advantage relative to the United States in an industry. A predominant role for resource seeking by U.S. firms would suggest moves toward countries with high comparative advantage relative to the United States in an industry.

Equation 1 relates changes in the industry composition of U.S. affiliate production (gross output) across seven broad manufacturing groups in a country to the country's export comparative advantage relative to the United States in that industry group at the beginning of each period.

(1) Change in VA share $=$ VAFI/VAFT $(t+1)-\operatorname{VAFI} / V A F T(t)=g[\operatorname{EXCAF} / \operatorname{EXCAUS}(\mathrm{t})(\mathrm{I})]$

Where VAFI= U.S. affiliate value added in industry group I in foreign country F $\mathrm{VAFT}=\mathrm{U} . \mathrm{S}$. affiliate value added in all manufacturing industries in country F. $\mathrm{EXCAF}=$ Export comparative advantage of foreign country $\mathrm{F}$ in industry $\mathrm{I}$. EXCAUS $=$ Export comparative advantage of the US in industry I.

The periods are of five to seven years in length and the number of countries in an industry group ranges from 9 to 14 .

The fitted equation, 1a, explains little of the change in U.S. affiliate production shares across countries in all industry groups. As far as it goes, the positive coefficient for EXCAF/EXCAUS(t) points to resource seeking rather than exploitation of U.S. firm comparative advantages as the explanation of changes in the location of U.S. affiliate production. 
(1a) Change in VA share $=a+1.078$ (3.26)EXCAF/EXCAUS

$$
\mathrm{RSQ}=.030 \quad \text { Prob }>\mathrm{F}=.001 \quad \text { No. Obs. }=314
$$

To the small extent that equation 1a explains the growth in U.S. FDI production, it says that such production moves to countries within each industry group where there are the highest export comparative advantages relative to the U.S. as a country.

The corresponding individual industry equations for individual time periods produce only one statistically significant coefficient at the five per cent level. That is for the food industries, and that is positive. Of the only two others that are significant at the ten per cent level, the coefficient for Primary and fabricated metals is positive, again suggesting a movement of production toward host country export comparative advantage. Only the coefficient for Non-electrical machinery is negative, indicating a move of U.S. production toward locations of initial export comparative disadvantage. We might interpret that result as suggesting that in the more resource-intensive broad sectors, U.S.-owned production moved toward locations of export comparative advantage, but that in machinery industries, it moved toward locations of initial export comparative disadvantage. Perhaps in these industries comparative advantage reflects technology differences more than differences in factor abundance.

\section{Conclusions}

Inward and outward foreign direct investment (FDI) stocks and flows seem to go together, across countries and over time. The countries that invest a lot in this form tend also to be large recipients of FDI, although there are some exceptions, particularly a few large recipients. The large recipients are a quite stable group; the best predictor of inward and outward stocks inflows and outflows this year or this quinquennium is the stocks or flows of the last period.

Large countries and countries with high ratios of capital formation to GDP in the preceding period tend to invest and receive less FDI, relative to their size, than others. Richer countries and those more open to trade, tend to invest and receive more FDI.

A surprising feature of the FDI data is the coincidence of FDI inflows and outflows; much of what FDI does must take place in these two-way, often offsetting, flows. 
Even gross FDI inflows have been small relative to gross fixed capital formation (GFCF). On average, gross inflows range up to 17 per cent of capital formation, but most country averages are 5 per cent or less. The net inflows average at most 10 per cent of GFCF, and for most countries are between -5 and +5 per cent of capital formation.

Past growth rates of per capita GDP and past ratios of capital formation to GDP are the main influences on current capital formation ratios. There is slight evidence of a negative effect of past FDI outflows, but coefficients for FDI inflows are also more often negative than positive. Net inflows of FDI do not seem to affect capital formation ratios at all. We take that lack of influence to be a sign that the financing of capital formation is not a role that FDI flows play in most of these developed countries.

Since much of FDI consists of offsetting two-way flows, we suggest that the main role FDI plays is that of transferring assets from less efficient to more efficient owners. Some crude evidence for the United States relative to the rest of the world seems to conform to this picture. Outward FDI production and outward relative to inward FDI production tends to be higher in industries of earlier U.S. export comparative advantage, while inward FDI does not come to such industries.

A bilateral test across countries of changes in the distribution of U.S. affiliate production among broad industry groups finds little explanation for these changes in country comparative advantages relative to the United States. Overall, and in foods and metals, U.S. affiliate production moved toward countries with relative comparative advantages in each industry group, suggesting the influence of country factor endowments. However, in nonelectrical machinery, there were signs that U.S. production moved toward countries with comparative disadvantages in the industry, suggesting the influence of U.S. firm technological advantages.

If FDI is transferring assets and production from less efficient to more efficient owners and managers, it can be viewed in recipient countries as freeing capital frozen in industries that the owners (including governments) would like to leave. It permits the owners to use their capital in what they consider more appropriate ways, at home or abroad. In the investing countries, outward FDI permits the country's firms 
to optimally exploit their skills and comparative advantages, perhaps lost to the home countries, but retained by the firms. 


\section{$\underline{\text { References }}$}

Aitken, Brian, Ann Harrison, and Robert E. Lipsey (1996), "Wages and Foreign Ownership: A Comparative Study of Mexico, Venezuela, and the United States,” Journal of International Economics, Vol. 40, pp. 343-371, May.

Conyon, M.S., S. Girma, S. Thompson, and P. Wright (1999), "The Impact of Foreign Acquisition on Wages and Productivity in the UK," Centre for Research on Globalisation and Labour Markets, School of Economics, University of Nottingham, Research Paper 99/8.

Fahim-Nader, Mahnaz, and William J. Zeile (1997), "Foreign Direct Investment in the United States: New Investment in 1996, Affiliate Operations in 1995," Survey of Current Business, Vol. 77, No. 6, June, pp. 42-69.

Feliciano, Zadia, and Robert E. Lipsey, "Foreign Ownership and Wages in the United States, 1987-1992," NBER Working Paper No. 6923, Cambridge, MA, National Bureau of Economic Research, February.

International Monetary Fund, or IMF (1999), Balance of Payments Statistics Yearbook, 1999, Part 2: World and Regional Tables, Washington, DC.

Jost, Thomas (1997), "Direct Investment and Germany as a Business Location,” Discussion Paper 2/97, Frankfurt am Main, Economic Research Group of the Deutsche Bundesbank, June.

Lichtenberg, Frank R. (1992), Corporate Takeovers and Productivity, Cambridge, MA, The MIT Press. Lipsey, Robert E. (1999a), "Foreign Production by U.S. Firms and Parent Firm Employment,” NBER Working Paper No. 7357, Cambridge, MA, NBER, September. (1999b), “The Role of FDI in International Capital Flows," in Martin Feldstein, editor, International Capital Flows, Chicago, University of Chicago Press.

Lubitz, Raymond (1966), "United States Direct Investment in Canada and Canadian Capital Formation, 1950-1962," Ph.D. Dissertation, Harvard University, Cambridge, MA, October.

Organisation for Economic Cooperation and Development, or OECD (1998), International Direct Investment Statistics Yearbook, 1998, Paris, OECD. 
U.S. Department of Commerce (1981), U.S. Direct Investment Abroad, 1977 Benchmark Survey, Washington, DC, Bureau of Economic Analysis. (1985), U.S. Direct Investment Abroad, 1982 Benchmark Survey Data, Washington, DC, Bureau of Economic Analysis. (1992), U.S. Direct Investment Abroad, 1989 Benchmark Survey, Final

Results, Washington, DC, Bureau of Economic Analysis, October. (1998), U.S. Direct Investment Abroad, 1994 Benchmark Survey, Final Results, Washington, DC, Bureau of Economic Analysis, May. Van Loo, Frances (1977), “The Effect of Foreign Direct Investment on Investment in Canada," Review of Economics and Statistics, Vol. LIX, No. 4, November, pp. 474-481. 


\section{$\underline{\text { Data Sources }}$}

\section{FDI Inward Stock :}

International Financial Statistics June 1998 CD_ROM, International Monetary Fund. International Direct Investment Statistics Yearbook (1998), on diskettes, OECD (Paris). World Investment Report 1999, Annex table B.3., pp. 489, United Nations (New York). International Investment and Multinational Enterprises, Recent Trends in International Direct Investment (1987), Table I.6, pp. 63, OECD (Paris).

\section{FDI Outward Stock:}

International Direct Investment Statistics Yearbook (1998), on diskettes, OECD (Paris).

World Investment Report 1999, Annex table B.4, pp. 495, United Nations (New York). International Investment and Multinational Enterprises, Recent Trends in International Direct Investment (1987), Table I.7, pp. 64, OECD (Paris).

Transnational Corporations in World Development, Trends and Prospects (1988), Annex Table A.5, pp. 518, United Nations (New York).

\section{FDI Inward Flow:}

International Financial Statistics June 1998 CD-ROM, International Monetary Fund. 1970-75 Belgium-Luxembourg, Greece, Iceland and Ireland: International Financial Statistics Yearbook (1994), Vol. XLVII, International Monetary Fund.

\section{FDI Outward Flow:}

International Financial Statistics June 1998 CD ROM, International Monetary Fund.

\section{Nominal GDP:}

World Development Indicators CD-ROM (1998), World Bank.

1965-90 Germany: OECD Statistics on Microcomputer Diskette, Annual National Accounts, Vol. 1, Main Aggregates, 1960-1994, OECD (Paris).

Exchange rates from International Financial Statistics (1998), International Monetary Fund.

\section{Real GDP Per Capita in Constant International Dollars:}

1965-1990: $\quad$ Penn World Tables, Version 5.6.

1991-1995: $\quad$ World Development Indicators CD-ROM (1998), World Bank.

\section{Real GDP Per Capita in Current International Dollars:}

1965-1990: $\quad$ Penn World Tables, Version 5.6

1991-1995: World Development Indicators CD-ROM (1998), World Bank.

Gross Fixed Capital Formation, Public Fixed Capital Formation and Corporate and QuasiCorporate Fixed Capital Formation:

National Accounts, Detailed Tables, 1960/1997, 1999 Edition, CD-ROM, OECD (Paris).

\section{Trade Ratio:}

World Development Indicators CD-ROM (1998), World Bank.

Germany: $\quad$ Trade Ratio $=($ Export + Import $) /$ Nominal GDP $* 100$

1966-70 import \& export: Statistisches Jahrbuch, für die Bundesrepublik

Deutschland (1971), Statistisches Bundesamt, pp. 279.

1970-95 import \& export: Statistisches Jahrbuch, für die Bundesrepublik Deutschland (1998), Statistisches Bundesamt, pp. 269. 
Tax Paid by Affiliates = Income Tax Paid by Affiliates / Total Sales of Affiliates * 100:

(US MOFA in foreign countries and foreign nonbank affiliates in US)

U.S. Direct Investment Abroad, Benchmark Survey (1966, 1977, 1982, 1989 and 1994), US Dept. of Commerce.

US: Foreign Direct Investment in the United States (1966, 1977, 1982, 1989 and 1994), US Dept. of Commerce.

Payroll Per Employee = Employee Compensation in Affiliates / Employment in Affiliates *100:

(US MOFA in foreign countries and foreign nonbank affiliates in US)

U.S. Direct Investment Abroad, Benchmark Survey (1966, 1977, 1982, 1989 and 1994), US Dept. of Commerce.

US: Foreign Direct Investment in the United States, US Dept. of Commerce (1985, 1992, and 1997), US. US Dept. of Commerce.

Foreign Direct Investment in the United States, 1977-80 (1985), US Dept. of Commerce.

\section{Value Added:}

(US MOFA in foreign countries and foreign nonbank affiliates in US)

U.S. Direct Investment Abroad, Benchmark Survey (1977, 1982, 1989 and 1994), US Dept. of Commerce. 
Table 1. Relation of Outflows of FDI to Inflows, 1977 - 1995

\begin{tabular}{|c|c|c|c|c|c|c|c|}
\hline Equation & Dependent Variable & & $\begin{array}{c}\text { Constant } \\
\text { Term }\end{array}$ & $\begin{array}{l}\text { Coefficient of } \\
\text { FDI Inflow }\end{array}$ & Adj. $\mathrm{R}^{2}$ & Prob. $>\mathrm{F}$ & $\begin{array}{c}\text { No. of } \\
\text { Obs. }\end{array}$ \\
\hline $1-1$ & $\begin{array}{l}\text { Cumulated } \\
\text { Outflow/GDP }\end{array}$ & All Countries & 0.776 & 0.434 & 0.138 & 0.071 & 18 \\
\hline $1-2$ & Annual Outflow & All Countries & $\begin{array}{l}(2.13) \\
2,027 \\
(5.47)\end{array}$ & $\begin{array}{c}(1.93) \\
0.868 \\
(21.52)\end{array}$ & 0.505 & 0.000 & 454 \\
\hline $1-3$ & Annual Outflow/GDP & All Countries & $\begin{array}{l}0.586 \\
(7.99)\end{array}$ & $\begin{array}{c}0.480 \\
(10.26)\end{array}$ & 0.187 & 0.000 & 454 \\
\hline
\end{tabular}


Table 2. Determinants of Inward FDI Stock Relative to GDP, 1970-1995 (5-Year Intervals)

\begin{tabular}{|c|c|c|c|c|c|c|}
\hline \multirow[t]{2}{*}{ Independent Variables } & \multicolumn{6}{|c|}{ Equation No. $^{\mathrm{a}}$} \\
\hline & $2-1$ & $\begin{array}{c}2-2 \text { (2-1 plus } \\
\text { country dummies) }\end{array}$ & $\begin{array}{l}\text { 2-3 (2-1 excluding } \\
\text { Japan \& U.S.) }\end{array}$ & $2-4$ & $2-5$ & $2-6$ \\
\hline Nominal GDP (-5) & $\begin{array}{l}-3.180 \\
(2.77)^{b}\end{array}$ & $\begin{array}{l}-0.614 \\
(0.45)\end{array}$ & $\begin{array}{l}-4.140 \\
(1.01)\end{array}$ & $\begin{array}{l}-3.389 \\
(3.04)\end{array}$ & $\begin{array}{l}-1.790 \\
(1.39)\end{array}$ & $\begin{array}{l}0.045 \\
(0.05)\end{array}$ \\
\hline Growth in Real GDP Per Cap. (-5) & $\begin{array}{l}-0.026 \\
(0.24)\end{array}$ & $\begin{array}{l}-0.002 \\
(0.02)\end{array}$ & $\begin{array}{l}-0.005 \\
(0.04)\end{array}$ & $\begin{array}{l}0.070 \\
(0.63)\end{array}$ & $\begin{array}{l}0.037 \\
(0.34)\end{array}$ & $\begin{array}{l}-0.160 \\
(1.96)\end{array}$ \\
\hline Real GDP Per Capita (-5) & $\begin{array}{l}0.466 \\
(2.28)\end{array}$ & $\begin{array}{l}0.453 \\
(2.90)\end{array}$ & $\begin{array}{l}0.397 \\
(1.69)\end{array}$ & $\begin{array}{l}0.418 \\
(2.10)\end{array}$ & $\begin{array}{l}0.293 \\
(1.45)\end{array}$ & $\begin{array}{l}0.103 \\
(0.69)\end{array}$ \\
\hline GFCF / GDP (-5) & & & & $\begin{array}{l}-0.591 \\
(2.43)\end{array}$ & $\begin{array}{l}-0.468 \\
(1.93)\end{array}$ & $\begin{array}{l}-0.113 \\
(0.61)\end{array}$ \\
\hline Trade (Exp. + Imp.) / GDP (-5) & & & & & $\begin{array}{l}0.079 \\
(2.30)\end{array}$ & $\begin{array}{l}0.048 \\
(1.89)\end{array}$ \\
\hline FDI Inward Stock / GDP (-5) & & & & & & $\begin{array}{l}0.827 \\
(9.12)\end{array}$ \\
\hline Adj. R-Sq. & 0.081 & 0.687 & 0.003 & 0.136 & 0.183 & 0.698 \\
\hline Prob $>F$ & 0.024 & 0.000 & 0.367 & 0.005 & 0.001 & 0.000 \\
\hline No. of Observations & 80 & 80 & 71 & 80 & 80 & 58 \\
\hline
\end{tabular}

\footnotetext{
${ }^{\text {a }}$ Constant term omitted

${ }^{\mathrm{b}} \mathrm{t}$-statistics in parentheses
} 
Table 3. Determinants of Inward FDI Flow Relative to GDP, 1970-1995 (5-Year Periods)

\begin{tabular}{|c|c|c|c|c|c|c|}
\hline \multirow[t]{2}{*}{ Independent Variables } & \multicolumn{6}{|c|}{ Equation No. $^{a}$} \\
\hline & $3-1$ & $\begin{array}{c}\text { 3-2 (3-1 plus } \\
\text { country dummies) }\end{array}$ & $\begin{array}{l}\text { 3-3 (3-1 excluding } \\
\text { Japan \& U.S.) }\end{array}$ & $3-4$ & $3-5$ & $3-6$ \\
\hline Nominal GDP (-5) & $\begin{array}{l}-0.406 \\
(2.86)^{b}\end{array}$ & $\begin{array}{l}-0.317 \\
(1.64)\end{array}$ & $\begin{array}{l}-1.052 \\
(2.15)\end{array}$ & $\begin{array}{l}-0.438 \\
(3.23)\end{array}$ & $\begin{array}{l}-0.258 \\
(1.70)\end{array}$ & $\begin{array}{l}-0.151 \\
(1.26)\end{array}$ \\
\hline Growth in Real GDP Per Cap. (-5) & $\begin{array}{l}-0.012 \\
(1.04)\end{array}$ & $\begin{array}{l}0.007 \\
(0.83)\end{array}$ & $\begin{array}{l}-0.010 \\
(0.87)\end{array}$ & $\begin{array}{l}-0.001 \\
(0.11)\end{array}$ & $\begin{array}{l}-0.004 \\
(0.36)\end{array}$ & $\begin{array}{l}-0.015 \\
(1.56)\end{array}$ \\
\hline Real GDP Per Capita (-5) & $\begin{array}{l}0.060 \\
(2.66)\end{array}$ & $\begin{array}{l}0.086 \\
(4.63)\end{array}$ & $\begin{array}{l}0.068 \\
(2.70)\end{array}$ & $\begin{array}{l}0.055 \\
(2.57)\end{array}$ & $\begin{array}{l}0.040 \\
(1.81)\end{array}$ & $\begin{array}{l}0.036 \\
(1.94)\end{array}$ \\
\hline GFCF / GDP (-5) & & & & $\begin{array}{l}-0.091 \\
(3.33)\end{array}$ & $\begin{array}{l}-0.080 \\
(2.97)\end{array}$ & $\begin{array}{l}-0.053 \\
(2.16)\end{array}$ \\
\hline Trade / GDP (-5) & & & & & $\begin{array}{l}0.009 \\
(2.41)\end{array}$ & $\begin{array}{l}0.004 \\
(1.27)\end{array}$ \\
\hline FDI Inward Flow / GDP (-5) & & & & & & $\begin{array}{l}0.810 \\
(8.90)\end{array}$ \\
\hline Adj. R-Sq. & 0.100 & 0.573 & 0.086 & 0.182 & 0.219 & 0.604 \\
\hline Prob $>F$ & 0.003 & 0.000 & 0.010 & 0.000 & 0.000 & 0.000 \\
\hline No. of Observations & 105 & 105 & 96 & 105 & 105 & 83 \\
\hline
\end{tabular}

\footnotetext{
${ }^{a}$ Constant term omitted

${ }^{\mathrm{b}} \mathrm{t}$-statistics in parentheses
} 
Table 4. Determinants of Annual Inward FDI Flow Relative to GDP, 1970-1995

\begin{tabular}{|c|c|c|c|c|c|c|}
\hline \multirow[t]{2}{*}{ Independent Variables } & \multicolumn{6}{|c|}{ Equation No. $^{\mathrm{a}}$} \\
\hline & $4-1$ & $\begin{array}{c}4-2 \text { (4-1 plus } \\
\text { country dummies) }\end{array}$ & $\begin{array}{l}\text { 4-3 (4-1 excluding } \\
\text { Japan \& U.S.) }\end{array}$ & $4-4$ & $4-5$ & $4-6$ \\
\hline Nominal GDP (-1) & $\begin{array}{l}-0.324 \\
(5.97)^{\mathrm{b}}\end{array}$ & $\begin{array}{l}-0.232 \\
(2.87)\end{array}$ & $\begin{array}{l}-0.667 \\
(3.72)\end{array}$ & $\begin{array}{l}-0.320 \\
5.96\end{array}$ & $\begin{array}{l}-0.205 \\
(3.36)\end{array}$ & $\begin{array}{r}-0.060 \\
(1.57)\end{array}$ \\
\hline Growth in Real GDP Per Cap. (-1) & $\begin{array}{l}0.054 \\
(2.96)\end{array}$ & $\begin{array}{l}0.079 \\
(5.79)\end{array}$ & $\begin{array}{l}0.061 \\
(3.15)\end{array}$ & $\begin{array}{l}0.063 \\
(3.42)\end{array}$ & $\begin{array}{l}0.055 \\
(3.04)\end{array}$ & $\begin{array}{l}0.031 \\
(2.68)\end{array}$ \\
\hline Real GDP Per Capita (-1) & $\begin{array}{l}0.063 \\
(6.53)\end{array}$ & $\begin{array}{l}0.079 \\
(9.09)\end{array}$ & $\begin{array}{l}0.066 \\
(6.19)\end{array}$ & $\begin{array}{l}0.055 \\
(5.63)\end{array}$ & $\begin{array}{l}0.046 \\
(4.61)\end{array}$ & $\begin{array}{l}0.015 \\
(2.29)\end{array}$ \\
\hline GFCF / GDP (-1) & & & & $\begin{array}{l}-0.045 \\
(3.41)\end{array}$ & $\begin{array}{l}-0.038 \\
(2.93)\end{array}$ & $\begin{array}{l}-0.021 \\
(2.52)\end{array}$ \\
\hline Trade / GDP (-1) & & & & & $\begin{array}{l}0.007 \\
(3.79)\end{array}$ & $\begin{array}{l}0.001 \\
(0.96)\end{array}$ \\
\hline FDI Inward Flow / GDP (-1) & & & & & & $\begin{array}{r}0.830 \\
(28.35)\end{array}$ \\
\hline Adj. R-Sq. & 0.103 & 0.523 & 0.087 & 0.122 & 0.146 & 0.686 \\
\hline Prob $>F$ & 0.000 & 0.000 & 0.000 & 0.000 & 0.000 & 0.000 \\
\hline No. of Observations & 494 & 494 & 449 & 494 & 494 & 470 \\
\hline
\end{tabular}

\footnotetext{
${ }^{\mathrm{a}}$ Constant term omitted

${ }^{\mathrm{b}} \mathrm{t}$-statistics in parentheses
} 
Table 5. Determinants of Outward FDI Stock Relative to GDP, 1970-1995 (5-Year Intervals)

\begin{tabular}{|c|c|c|c|c|c|c|}
\hline \multirow[t]{2}{*}{ Independent Variables } & \multicolumn{6}{|c|}{ Equation No. $^{\text {a }}$} \\
\hline & $5-1$ & $\begin{array}{c}5-2(5-1 \text { plus } \\
\text { country dummies })\end{array}$ & $\begin{array}{l}\text { 5-3 (5-1 excluding } \\
\text { Japan \& U.S.) }\end{array}$ & $5-4$ & $5-5$ & $5-6$ \\
\hline Nominal GDP (-5) & $\begin{array}{l}-1.495 \\
(1.26)^{b}\end{array}$ & $\begin{array}{l}-3.189 \\
(3.09)\end{array}$ & $\begin{array}{r}1.069 \\
(0.25)\end{array}$ & $\begin{array}{l}-1.688 \\
(1.46)\end{array}$ & $\begin{array}{l}-0.009 \\
(0.01)\end{array}$ & $\begin{array}{c}-0.354 \\
(0.61)\end{array}$ \\
\hline Growth in Real GDP Per Cap. (-5) & $\begin{array}{l}-0.105 \\
(0.99)\end{array}$ & $\begin{array}{l}0.011 \\
(0.21)\end{array}$ & $\begin{array}{l}-0.094 \\
(0.82)\end{array}$ & $\begin{array}{l}-0.021 \\
(0.19)\end{array}$ & $\begin{array}{l}-0.064 \\
(0.60)\end{array}$ & $\begin{array}{c}-0.078 \\
(1.45)\end{array}$ \\
\hline Real GDP Per Capita (-5) & $\begin{array}{l}0.739 \\
(3.60)\end{array}$ & $\begin{array}{l}0.863 \\
(8.03)\end{array}$ & $\begin{array}{l}0.718 \\
(3.02)\end{array}$ & $\begin{array}{l}0.678 \\
(3.37)\end{array}$ & $\begin{array}{l}0.553 \\
(2.73)\end{array}$ & $\begin{array}{l}0.339 \\
(3.30)\end{array}$ \\
\hline GFCF / GDP (-5) & & & & $\begin{array}{l}-0.609 \\
(2.36)\end{array}$ & $\begin{array}{l}-0.427 \\
(1.63)\end{array}$ & $\begin{array}{l}0.021 \\
(0.16)\end{array}$ \\
\hline Trade / GDP (-5) & & & & & $\begin{array}{l}0.081 \\
(2.36)\end{array}$ & $\begin{array}{l}0.038 \\
(2.24)\end{array}$ \\
\hline FDI Outward Stock / GDP (-5) & & & & & & $\begin{array}{r}1.028 \\
(17.82)\end{array}$ \\
\hline Adj. R-Sq. & 0.139 & 0.841 & 0.136 & 0.184 & 0.228 & 0.881 \\
\hline Prob $>F$ & 0.002 & 0.000 & 0.003 & 0.000 & 0.000 & 0.000 \\
\hline No. of Observations & 86 & 86 & 77 & 86 & 86 & 64 \\
\hline
\end{tabular}

\footnotetext{
${ }^{\text {a }}$ Constant term omitted

${ }^{b} t$-statistics in parentheses
} 
Table 6. Determinants of Outward FDI Flow Relative to GDP, 1970-1995 (5-Year Periods)

\begin{tabular}{|c|c|c|c|c|c|c|}
\hline \multirow[t]{2}{*}{ Independent Variables } & \multicolumn{6}{|c|}{ Equation No. ${ }^{a}$} \\
\hline & $6-1$ & $\begin{array}{c}6-2(6-1 \text { plus } \\
\text { country dummies })\end{array}$ & $\begin{array}{l}\text { 6-3 (6-1 excluding } \\
\text { Japan \& U.S.) }\end{array}$ & $6-4$ & $6-5$ & $6-6$ \\
\hline Nominal GDP (-5) & $\begin{array}{l}-0.378 \\
(2.50)^{\mathrm{b}}\end{array}$ & $\begin{array}{l}-0.490 \\
(3.03)\end{array}$ & $\begin{array}{l}-0.156 \\
(0.29)\end{array}$ & $\begin{array}{l}-0.403 \\
(2.72)\end{array}$ & $\begin{array}{l}-0.123 \\
(0.75)\end{array}$ & $\begin{array}{l}-0.024 \\
(0.19)\end{array}$ \\
\hline Growth in Real GDP Per Cap. (-5) & $\begin{array}{l}-0.013 \\
(1.02)\end{array}$ & $\begin{array}{l}0.002 \\
(0.20)\end{array}$ & $\begin{array}{l}-0.012 \\
(0.92)\end{array}$ & $\begin{array}{l}-0.005 \\
(0.39)\end{array}$ & $\begin{array}{l}-0.009 \\
(0.71)\end{array}$ & $\begin{array}{r}-0.017 \\
(1.51)\end{array}$ \\
\hline Real GDP Per Capita (-5) & $\begin{array}{l}0.116 \\
(4.72)\end{array}$ & $\begin{array}{l}0.123 \\
(7.77)\end{array}$ & $\begin{array}{l}0.112 \\
(3.94)\end{array}$ & $\begin{array}{l}0.110 \\
(4.57)\end{array}$ & $\begin{array}{l}0.086 \\
(3.55)\end{array}$ & $\begin{array}{l}0.026 \\
(1.15)\end{array}$ \\
\hline GFCF / GDP (-5) & & & & $\begin{array}{l}-0.072 \\
(2.32)\end{array}$ & $\begin{array}{l}-0.049 \\
(1.60)\end{array}$ & $\begin{array}{l}-0.024 \\
(0.86)\end{array}$ \\
\hline Trade / GDP (-5) & & & & & $\begin{array}{l}0.013 \\
(3.30)\end{array}$ & $\begin{array}{l}0.009 \\
(2.41)\end{array}$ \\
\hline FDI Outward Flow / GDP (-5) & & & & & & $\begin{array}{l}0.682 \\
(7.64)\end{array}$ \\
\hline Adj. R-Sq. & 0.222 & 0.774 & 0.207 & 0.257 & 0.329 & 0.646 \\
\hline Prob $>F$ & 0.000 & 0.000 & 0.000 & 0.000 & 0.000 & 0.000 \\
\hline No. of Observations & 97 & 97 & 88 & 97 & 97 & 75 \\
\hline
\end{tabular}

\footnotetext{
${ }^{\text {a }}$ Constant term omitted

${ }^{b} t$-statistics in parentheses
} 
Table 7. Determinants of Annual Outward FDI Flow Relative to GDP, 1970-1995

\begin{tabular}{|c|c|c|c|c|c|c|}
\hline \multirow[t]{2}{*}{ Independent Variables } & \multicolumn{6}{|c|}{ Equation No. $^{a}$} \\
\hline & $7-1$ & $\begin{array}{c}\text { 7-2 (7-1 plus } \\
\text { country dummies) }\end{array}$ & $\begin{array}{l}\text { 7-3 (7-1 excluding } \\
\text { Japan \& U.S.) }\end{array}$ & $7-4$ & $7-5$ & $7-6$ \\
\hline Nominal GDP (-1) & $\begin{array}{l}-0.296 \\
(5.00)^{\mathrm{b}}\end{array}$ & $\begin{array}{l}-0.412 \\
(5.17)\end{array}$ & $\begin{array}{l}-0.089 \\
(0.44)\end{array}$ & $\begin{array}{l}-0.292 \\
(4.99)\end{array}$ & $\begin{array}{l}-0.118 \\
(1.76)\end{array}$ & $\begin{array}{l}-0.041 \\
(0.86)\end{array}$ \\
\hline Growth in Real GDP Per Cap. (-1) & $\begin{array}{l}0.046 \\
(2.21)\end{array}$ & $\begin{array}{l}0.068 \\
(4.85)\end{array}$ & $\begin{array}{l}0.049 \\
(2.14)\end{array}$ & $\begin{array}{l}0.056 \\
(2.73)\end{array}$ & $\begin{array}{l}0.044 \\
(2.18)\end{array}$ & $\begin{array}{l}0.015 \\
(1.04)\end{array}$ \\
\hline Real GDP Per Capita (-1) & $\begin{array}{l}0.108 \\
(9.92)\end{array}$ & $\begin{array}{c}0.120 \\
(13.50)\end{array}$ & $\begin{array}{l}0.106 \\
(8.62)\end{array}$ & $\begin{array}{l}0.097 \\
(8.71)\end{array}$ & $\begin{array}{l}0.082 \\
(7.27)\end{array}$ & $\begin{array}{l}0.023 \\
(2.68)\end{array}$ \\
\hline GFCF / GDP (-1) & & & & $\begin{array}{l}-0.056 \\
(3.68)\end{array}$ & $\begin{array}{l}-0.042 \\
(2.78)\end{array}$ & $\begin{array}{l}-0.026 \\
(2.40)\end{array}$ \\
\hline Trade / GDP (-1) & & & & & $\begin{array}{l}0.011 \\
(4.97)\end{array}$ & $\begin{array}{l}0.004 \\
(2.15)\end{array}$ \\
\hline FDI Outward Flow / GDP (-1) & & & & & & $\begin{array}{c}0.725 \\
(20.97)\end{array}$ \\
\hline Adj. R-Sq. & 0.177 & 0.655 & 0.166 & 0.199 & 0.239 & 0.627 \\
\hline Prob $>F$ & 0.000 & 0.000 & 0.000 & 0.000 & 0.000 & 0.000 \\
\hline No. of Observations & 454 & 454 & 409 & 454 & 454 & 431 \\
\hline
\end{tabular}

\footnotetext{
${ }^{\text {a }}$ Constant term omitted

${ }^{\mathrm{b}} \mathrm{t}$-statistics in parentheses
} 
Table 8. Determinants of Net Inward FDI Stock Relative to GDP, 1970-1995 (5-Year Intervals)

\begin{tabular}{|c|c|c|c|c|c|c|}
\hline \multirow[t]{2}{*}{ Independent Variables } & \multicolumn{6}{|c|}{ Equation No. $^{\mathrm{a}}$} \\
\hline & $8-1$ & $\begin{array}{c}\text { 8-2 (8-1 plus } \\
\text { country dummies) }\end{array}$ & $\begin{array}{l}\text { 8-3 (8-1 excluding } \\
\text { Japan \& U.S.) }\end{array}$ & $8-4$ & $8-5$ & $8-6$ \\
\hline Nominal GDP (-5) & $\begin{array}{c}1.638 \\
(1.25)^{\mathrm{b}}\end{array}$ & $\begin{array}{l}2.599 \\
(2.10)\end{array}$ & $\begin{array}{l}-5.279 \\
(1.12)\end{array}$ & $\begin{array}{l}-1.643 \\
(1.24)\end{array}$ & $\begin{array}{l}-1.858 \\
(1.15)\end{array}$ & $\begin{array}{l}0.314 \\
(0.33)\end{array}$ \\
\hline Growth in Real GDP Per Cap. (-5) & $\begin{array}{l}0.148 \\
(1.15)\end{array}$ & $\begin{array}{l}0.019 \\
(0.28)\end{array}$ & $\begin{array}{l}0.172 \\
(1.25)\end{array}$ & $\begin{array}{l}0.150 \\
(1.09)\end{array}$ & $\begin{array}{l}0.154 \\
(1.10)\end{array}$ & $\begin{array}{l}-0.057 \\
(0.63)\end{array}$ \\
\hline Real GDP Per Capita (-5) & $\begin{array}{c}-0.268 \\
(1.09)\end{array}$ & $\begin{array}{l}-0.441 \\
(3.08)\end{array}$ & $\begin{array}{l}-0.337 \\
(1.20)\end{array}$ & $\begin{array}{l}-0.269 \\
(1.08)\end{array}$ & $\begin{array}{l}-0.253 \\
(0.98)\end{array}$ & $\begin{array}{l}-0.135 \\
(0.79)\end{array}$ \\
\hline GFCF / GDP (-5) & & & & $\begin{array}{l}-0.014 \\
(0.05)\end{array}$ & $\begin{array}{l}-0.035 \\
(0.11)\end{array}$ & $\begin{array}{l}0.009 \\
(0.04)\end{array}$ \\
\hline Trade / GDP (-5) & & & & & $\begin{array}{l}-0.011 \\
(0.24)\end{array}$ & $\begin{array}{l}-0.007 \\
(0.25)\end{array}$ \\
\hline FDI Net Inward Stock / GDP (-5) & & & & & & $\begin{array}{r}0.840 \\
(10.29)\end{array}$ \\
\hline Adj. R-Sq. & 0.042 & 0.802 & 0.053 & 0.028 & 0.015 & 0.695 \\
\hline Prob $>F$ & 0.111 & 0.000 & 0.096 & 0.201 & 0.307 & 0.000 \\
\hline No. of Observations & 75 & 75 & 66 & 75 & 75 & 53 \\
\hline
\end{tabular}

\footnotetext{
${ }^{\text {a }}$ Constant term omitted

${ }^{b} t$-statistics in parentheses
} 
Table 9. Determinants of Net Inward FDI Flow Relative to GDP, 1970-1995 (5-Year Periods)

\begin{tabular}{|c|c|c|c|c|c|c|}
\hline \multirow[t]{2}{*}{ Independent Variables } & \multicolumn{6}{|c|}{ Equation No. $^{\mathrm{a}}$} \\
\hline & $9-1$ & $\begin{array}{c}\text { 9-2 (9-1 plus } \\
\text { country dummies) }\end{array}$ & $\begin{array}{l}\text { 9-3 (9-1 excluding } \\
\text { Japan \& U.S.) }\end{array}$ & $9-4$ & $9-5$ & $9-6$ \\
\hline Nominal GDP (-5) & $\begin{array}{l}-0.039 \\
(0.23)^{\mathrm{b}}\end{array}$ & $\begin{array}{l}0.142 \\
(0.72)\end{array}$ & $\begin{array}{l}-0.947 \\
(1.62)\end{array}$ & $\begin{array}{l}-0.045 \\
(0.27)\end{array}$ & $\begin{array}{l}-0.119 \\
(0.60)\end{array}$ & $\begin{array}{l}-0.130 \\
(0.79)\end{array}$ \\
\hline Growth in Real GDP Per Cap. (-5) & $\begin{array}{l}0.016 \\
(0.00)\end{array}$ & $\begin{array}{l}-1.990 \\
(0.21)\end{array}$ & $\begin{array}{l}1.934 \\
(0.13)\end{array}$ & $\begin{array}{l}1.978 \\
(0.14)\end{array}$ & $\begin{array}{l}2.932 \\
(0.20)\end{array}$ & $\begin{array}{c}-10.740 \\
(0.77)\end{array}$ \\
\hline Real GDP Per Capita (-5) & $\begin{array}{c}-0.051 \\
(1.86)\end{array}$ & $\begin{array}{l}-0.032 \\
(1.67)\end{array}$ & $\begin{array}{l}-0.038 \\
(1.24)\end{array}$ & $\begin{array}{l}-0.052 \\
(1.89)\end{array}$ & $\begin{array}{l}-0.046 \\
(1.57)\end{array}$ & $\begin{array}{l}0.020 \\
(0.74)\end{array}$ \\
\hline GFCF / GDP (-5) & & & & $\begin{array}{c}-0.018 \\
(0.51)\end{array}$ & $\begin{array}{l}-0.025 \\
(0.67)\end{array}$ & $\begin{array}{l}-0.016 \\
(0.45)\end{array}$ \\
\hline Trade / GDP (-5) & & & & & $\begin{array}{l}-0.004 \\
(0.72)\end{array}$ & $\begin{array}{l}-0.003 \\
(0.60)\end{array}$ \\
\hline FDI Net Inward Flow / GDP (-5) & & & & & & $\begin{array}{l}0.805 \\
(7.61)\end{array}$ \\
\hline Adj. R-Sq. & 0.023 & 0.659 & 0.056 & 0.015 & 0.010 & 0.438 \\
\hline Prob $>F$ & 0.163 & 0.000 & 0.049 & 0.252 & 0.320 & 0.000 \\
\hline No. of Observations & 97 & 97 & 88 & 97 & 97 & 75 \\
\hline
\end{tabular}

${ }^{\text {a }}$ Constant term omitted

${ }^{\mathrm{b}} \mathrm{t}$-statistics in parentheses 
Table 10. Determinants of Annual Net Inward FDI Flow Relative to GDP, 1970-1995

\begin{tabular}{|c|c|c|c|c|c|c|}
\hline \multirow[t]{2}{*}{ Independent Variables } & \multicolumn{6}{|c|}{ Equation No. $^{a}$} \\
\hline & $10-1$ & $\begin{array}{c}10-2 \text { (10-1 plus } \\
\text { country dummies) }\end{array}$ & $\begin{array}{l}\text { 10-3 (10-1 excluding } \\
\text { Japan \& U.S.) }\end{array}$ & $10-4$ & $10-5$ & $10-6$ \\
\hline Nominal GDP (-1) & $\begin{array}{l}-0.036 \\
(0.56)^{\mathrm{b}}\end{array}$ & $\begin{array}{l}0.134 \\
(1.42)\end{array}$ & $\begin{array}{l}-0.617 \\
(2.83)\end{array}$ & $\begin{array}{l}-0.037 \\
(0.56)\end{array}$ & $\begin{array}{l}-0.083 \\
(1.08)\end{array}$ & $\begin{array}{r}-0.037 \\
(0.66)\end{array}$ \\
\hline Growth in Real GDP Per Cap. (-1) & $\begin{array}{l}0.010 \\
(0.46)\end{array}$ & $\begin{array}{l}0.008 \\
(0.45)\end{array}$ & $\begin{array}{l}0.016 \\
(0.66)\end{array}$ & $\begin{array}{l}0.009 \\
(0.41)\end{array}$ & $\begin{array}{l}0.013 \\
(0.54)\end{array}$ & $\begin{array}{l}0.017 \\
(1.02)\end{array}$ \\
\hline Real GDP Per Capita (-1) & $\begin{array}{l}-0.041 \\
(3.38)\end{array}$ & $\begin{array}{l}-0.033 \\
(3.10)\end{array}$ & $\begin{array}{l}-0.035 \\
(2.67)\end{array}$ & $\begin{array}{l}-0.040 \\
(3.17)\end{array}$ & $\begin{array}{l}-0.036 \\
(2.75)\end{array}$ & $\begin{array}{r}-0.004 \\
(0.41)\end{array}$ \\
\hline GFCF / GDP (-5) & & & & $\begin{array}{l}0.006 \\
(0.32)\end{array}$ & $\begin{array}{l}0.002 \\
(0.10)\end{array}$ & $\begin{array}{c}0.003 \\
0.26\end{array}$ \\
\hline Trade / GDP (-1) & & & & & $\begin{array}{l}-0.003 \\
(1.15)\end{array}$ & $\begin{array}{c}-0.001 \\
(0.71)\end{array}$ \\
\hline FDI Net Inward Flow / GDP (-1) & & & & & & $\begin{array}{r}0.728 \\
(20.54)\end{array}$ \\
\hline Adj. R-Sq. & 0.030 & 0.532 & 0.054 & 0.028 & 0.029 & 0.512 \\
\hline Prob $>F$ & 0.001 & 0.000 & 0.000 & 0.002 & 0.003 & 0.000 \\
\hline No. of Observations & 453 & 453 & 408 & 453 & 453 & 429 \\
\hline
\end{tabular}

\footnotetext{
${ }^{\text {a }}$ Constant term omitted

${ }^{\mathrm{b}} \mathrm{t}$-statistics in parentheses
} 
Table 11. Average Ratios of FDI to GFCF: Available Years, 1970-1995

\begin{tabular}{lrr}
\hline & & \\
& Inward FDI / GFCF & Net Inward FDI / GFCF \\
\hline & & \\
Australia & 8.00 & 4.38 \\
Austria & 1.65 & -0.46 \\
Belg.-Lux & 14.65 & 4.41 \\
Canada & 6.00 & 0.52 \\
Denmark & 4.80 & -0.62 \\
Finland & 2.02 & -3.33 \\
France & 4.68 & -1.82 \\
Germany & 1.08 & -3.53 \\
Greece & 4.53 & 4.53 \\
Iceland & 1.34 & 1.12 \\
Ireland & 7.74 & 5.93 \\
Italy & 1.70 & -0.59 \\
Japan & 0.07 & -2.26 \\
Netherlands & 10.14 & -9.36 \\
New Zealand & 16.68 & 10.29 \\
Norway & 3.47 & -0.80 \\
Portugal & 6.07 & 5.00 \\
Spain & 7.61 & 5.62 \\
Sweden & 6.63 & -6.33 \\
Switzerland & 4.73 & -7.98 \\
United Kingdom & 10.25 & -5.32 \\
United States & 3.69 & -0.01 \\
& & \\
\hline
\end{tabular}


Table 12. Determinants of Total Capital Formation Ratios (GFCF/GDP), 1975-1995 (5-Year Periods)

\begin{tabular}{|c|c|c|c|c|c|c|c|c|}
\hline \multirow{3}{*}{ Equation No. ${ }^{a}$} & \multicolumn{5}{|c|}{ Coefficients for } & \multirow{3}{*}{ Adj. $R^{2}$} & \multirow{3}{*}{ Prob. > F } & \multirow{3}{*}{ No. of Obs } \\
\hline & Growth in Real GDP & \multicolumn{3}{|c|}{ FDI Flow / GDP } & \multirow{2}{*}{$\begin{array}{c}\text { GFCF / } \\
\operatorname{GDP}(-5)\end{array}$} & & & \\
\hline & Per Cap. (-5) & Inward (-5) & Outward (-5) & Net Inward (-5) & & & & \\
\hline $12-1$ & $\begin{array}{c}0.132 \\
(2.80)^{\mathrm{b}}\end{array}$ & $\begin{array}{l}-0.800 \\
(1.74)\end{array}$ & & & & 0.093 & 0.007 & 83 \\
\hline $12-2$ & $\begin{array}{l}0.104 \\
(2.13)\end{array}$ & & $\begin{array}{l}-0.126 \\
(3.39)\end{array}$ & & & 0.179 & 0.000 & 75 \\
\hline $12-3$ & $\begin{array}{l}0.109 \\
(2.07)\end{array}$ & & & $\begin{array}{l}0.563 \\
(1.37)\end{array}$ & & 0.072 & 0.026 & 75 \\
\hline $12-4$ & $\begin{array}{l}0.107 \\
(2.17)\end{array}$ & $\begin{array}{l}-0.293 \\
(0.57)\end{array}$ & $\begin{array}{l}-1.147 \\
(2.74)\end{array}$ & & & 0.171 & 0.001 & 75 \\
\hline $12-5$ & $\begin{array}{l}0.000 \\
(0.01)\end{array}$ & $\begin{array}{l}-0.393 \\
(1.34)\end{array}$ & & & $\begin{array}{c}0.801 \\
(11.02)\end{array}$ & 0.638 & 0.000 & 83 \\
\hline $12-6$ & $\begin{array}{l}-0.019 \\
(0.58)\end{array}$ & & $\begin{array}{l}-0.495 \\
(2.07)\end{array}$ & & $\begin{array}{c}0.802 \\
(10.86)\end{array}$ & 0.687 & 0.000 & 75 \\
\hline $12-7$ & $\begin{array}{l}-0.022 \\
(0.67)\end{array}$ & & & $\begin{array}{l}0.197 \\
(0.80)\end{array}$ & $\begin{array}{c}0.840 \\
(11.50)\end{array}$ & 0.671 & 0.000 & 75 \\
\hline $12-8$ & $\begin{array}{l}-0.016 \\
(0.49)\end{array}$ & $\begin{array}{l}-0.197 \\
(0.62)\end{array}$ & $\begin{array}{l}-0.423 \\
(1.59)\end{array}$ & & $\begin{array}{c}0.801 \\
(10.79)\end{array}$ & 0.684 & 0.000 & 75 \\
\hline
\end{tabular}

\footnotetext{
${ }^{a}$ Constant term omitted
}

${ }^{\mathrm{b}} \mathrm{t}$-statistics in parentheses 
Table 13. Determinants of Public Capital Formation Ratios (PGFCF/GDP), 1975-1995 (5-Year Periods)

\begin{tabular}{|c|c|c|c|c|c|c|c|c|}
\hline \multirow{3}{*}{ Equation No. ${ }^{a}$} & \multicolumn{5}{|c|}{ Coefficients for } & \multirow{3}{*}{ Adj. $R^{2}$} & \multirow{3}{*}{ Prob. $>\mathrm{F}$} & \multirow{3}{*}{ No. of Obs. } \\
\hline & Growth in Real GDP & \multicolumn{3}{|c|}{ FDI Flow / GDP } & \multirow{2}{*}{$\begin{array}{l}\text { PGFCF / } \\
\text { GDP (-5) }\end{array}$} & & & \\
\hline & Per Cap. $(-5)$ & 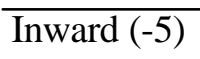 & Outward (-5) & Net Inward (-5) & & & & \\
\hline $13-1$ & $\begin{array}{c}0.037 \\
(2.74)^{\mathrm{b}}\end{array}$ & $\begin{array}{l}-0.467 \\
(3.28)\end{array}$ & & & & 0.172 & 0.001 & 67 \\
\hline $13-2$ & $\begin{array}{l}0.028 \\
(1.88)\end{array}$ & & $\begin{array}{l}0.189 \\
(1.74)\end{array}$ & & & 0.076 & 0.034 & 64 \\
\hline $13-3$ & $\begin{array}{l}0.034 \\
(2.13)\end{array}$ & & & $\begin{array}{l}-0.093 \\
(0.75)\end{array}$ & & 0.039 & 0.112 & 64 \\
\hline $13-4$ & $\begin{array}{l}0.039 \\
(2.64)\end{array}$ & $\begin{array}{l}-0.456 \\
(2.71)\end{array}$ & $\begin{array}{l}-0.032 \\
(0.27)\end{array}$ & & & 0.163 & 0.003 & 64 \\
\hline $13-5$ & $\begin{array}{l}0.018 \\
(2.01)\end{array}$ & $\begin{array}{l}-0.139 \\
(1.52)\end{array}$ & & & $\begin{array}{l}0.685 \\
(8.92)\end{array}$ & 0.674 & 0.000 & 58 \\
\hline $13-6$ & $\begin{array}{l}0.020 \\
(2.18)\end{array}$ & & $\begin{array}{l}-0.026 \\
(0.38)\end{array}$ & & $\begin{array}{l}0.728 \\
(9.70)\end{array}$ & 0.680 & 0.000 & 56 \\
\hline $13-7$ & $\begin{array}{l}0.023 \\
(2.44)\end{array}$ & & & $\begin{array}{l}-0.072 \\
(1.03)\end{array}$ & $\begin{array}{c}0.733 \\
(10.19)\end{array}$ & 0.685 & 0.000 & 56 \\
\hline $13-8$ & $\begin{array}{l}0.025 \\
(2.68)\end{array}$ & $\begin{array}{l}-0.177 \\
(1.76)\end{array}$ & $\begin{array}{l}0.029 \\
(0.40)\end{array}$ & & $\begin{array}{l}0.693 \\
(9.10)\end{array}$ & 0.692 & 0.000 & 56 \\
\hline
\end{tabular}

${ }^{a}$ Constant term omitted

${ }^{\mathrm{b}} \mathrm{t}$-statistics in parentheses 
Table 14. Determinants of Corporate and Quasi-Corporate Enterprise Capital Formation Ratios (CGFCF/GDP), 1975-1995 (5-Year Periods)

\begin{tabular}{|c|c|c|c|c|c|c|c|c|}
\hline \multirow{3}{*}{ Equation No. ${ }^{\mathrm{a}}$} & \multicolumn{5}{|c|}{ Coefficients for } & \multirow{3}{*}{ Adj. $R^{2}$} & \multirow{3}{*}{ Prob. $>\mathrm{F}$} & \multirow{3}{*}{ No. of Obs } \\
\hline & \multirow{2}{*}{$\begin{array}{c}\text { Growth in Real GDP } \\
\text { Per Cap. }(-5)\end{array}$} & \multicolumn{3}{|c|}{ FDI Flow / GDP } & \multirow{2}{*}{$\begin{array}{l}\text { CGFCF / } \\
\operatorname{GDP}(-5)\end{array}$} & & & \\
\hline & & Inward (-5) & Outward $(-5)$ & Net Inward (-5) & & & & \\
\hline $14-1$ & $\begin{array}{c}0.055 \\
(1.07)^{b}\end{array}$ & $\begin{array}{l}-1.075 \\
(2.05)\end{array}$ & & & & 0.043 & 0.110 & 59 \\
\hline $14-2$ & $\begin{array}{l}0.035 \\
(0.66)\end{array}$ & & $\begin{array}{l}-0.211 \\
(0.54)\end{array}$ & & & -0.022 & 0.675 & 58 \\
\hline $14-3$ & $\begin{array}{l}0.051 \\
(0.95)\end{array}$ & & & $\begin{array}{l}-0.381 \\
(0.91)\end{array}$ & & -0.012 & 0.518 & 58 \\
\hline $14-4$ & $\begin{array}{l}0.064 \\
(1.21)\end{array}$ & $\begin{array}{l}-1.196 \\
(2.02)\end{array}$ & $\begin{array}{l}0.175 \\
(0.41)\end{array}$ & & & 0.033 & 0.191 & 58 \\
\hline $14-5$ & $\begin{array}{l}-0.033 \\
(0.92)\end{array}$ & $\begin{array}{l}-0.416 \\
(1.25)\end{array}$ & & & $\begin{array}{l}0.772 \\
(8.24)\end{array}$ & 0.613 & 0.000 & 51 \\
\hline $14-6$ & $\begin{array}{l}-0.056 \\
(1.67)\end{array}$ & & $\begin{array}{l}-0.531 \\
(2.20)\end{array}$ & & $\begin{array}{l}0.825 \\
(9.31)\end{array}$ & 0.638 & 0.000 & 51 \\
\hline $14-7$ & $\begin{array}{l}-0.068 \\
(1.81)\end{array}$ & & & $\begin{array}{r}0.404 \\
(1.44)\end{array}$ & $\begin{array}{l}0.846 \\
(8.84)\end{array}$ & 0.617 & 0.000 & 51 \\
\hline $14-8$ & $\begin{array}{l}-0.054 \\
(1.45)\end{array}$ & $\begin{array}{l}-0.073 \\
(0.19)\end{array}$ & $\begin{array}{l}-0.504 \\
(1.78)\end{array}$ & & $\begin{array}{l}0.819 \\
(8.59)\end{array}$ & 0.630 & 0.000 & 51 \\
\hline
\end{tabular}

${ }^{\text {a }}$ Constant term omitted

${ }^{\mathrm{b}} \mathrm{t}$-statistics in parentheses 
Table 15. Determinants of Corporate and Quasi-Corporate Enterprise Capital Formation Ratios (CGFCF/GDP), 1975-1995 (Annual Data)

\begin{tabular}{|c|c|c|c|c|c|c|c|c|}
\hline \multirow{3}{*}{ Equation No. ${ }^{\mathrm{a}}$} & \multicolumn{5}{|c|}{ Coefficients for } & \multirow{3}{*}{ Adj. $R^{2}$} & \multirow{3}{*}{ Prob. $>$ F } & \multirow{3}{*}{ No. of Obs } \\
\hline & Growth in Real GDP & \multicolumn{3}{|c|}{ FDI Flow / GDP } & \multirow{2}{*}{$\begin{array}{l}\text { CGFCF / } \\
\text { GDP (-5) }\end{array}$} & & & \\
\hline & Per Cap. (-5) & Inward $(-5)$ & Outward $(-5)$ & Net Inward (-5) & & & & \\
\hline $15-1$ & $\begin{array}{c}0.358 \\
(5.43)^{\mathrm{b}}\end{array}$ & $\begin{array}{l}-0.433 \\
(2.56)\end{array}$ & & & & 0.097 & 0.000 & 298 \\
\hline $15-2$ & $\begin{array}{l}0.333 \\
(4.95)\end{array}$ & & $\begin{array}{l}0.013 \\
(0.09)\end{array}$ & & & 0.071 & 0.000 & 294 \\
\hline $15-3$ & $\begin{array}{l}0.341 \\
(5.08)\end{array}$ & & & $\begin{array}{l}-0.292 \\
(2.05)\end{array}$ & & 0.085 & 0.000 & 293 \\
\hline $15-4$ & $\begin{array}{l}0.350 \\
(5.21)\end{array}$ & $\begin{array}{l}-0.499 \\
(2.65)\end{array}$ & $\begin{array}{l}0.186 \\
(1.19)\end{array}$ & & & 0.090 & 0.000 & 293 \\
\hline $15-5$ & $\begin{array}{l}0.147 \\
(8.04)\end{array}$ & $\begin{array}{l}-0.136 \\
(2.93)\end{array}$ & & & $\begin{array}{c}0.928 \\
(60.29)\end{array}$ & 0.935 & 0.000 & 290 \\
\hline $15-6$ & $\begin{array}{l}0.139 \\
(7.41)\end{array}$ & & $\begin{array}{l}0.014 \\
(0.36)\end{array}$ & & $\begin{array}{c}0.931 \\
(59.91)\end{array}$ & 0.932 & 0.000 & 287 \\
\hline $15-7$ & $\begin{array}{l}0.142 \\
(7.67)\end{array}$ & & & $\begin{array}{l}-0.107 \\
(2.72)\end{array}$ & $\begin{array}{c}0.928 \\
(60.18)\end{array}$ & 0.934 & 0.000 & 286 \\
\hline $15-8$ & $\begin{array}{l}0.145 \\
(7.84)\end{array}$ & $\begin{array}{l}-0.167 \\
(3.24)\end{array}$ & $\begin{array}{l}0.075 \\
(1.74)\end{array}$ & & $\begin{array}{c}0.926 \\
(60.03)\end{array}$ & 0.934 & 0.000 & 286 \\
\hline
\end{tabular}

\footnotetext{
${ }^{\text {a }}$ Constant term omitted
}

${ }^{\mathrm{b}} \mathrm{t}$-statistics in parentheses 

Table 16. U.S. Export Comparative Advantage, 1970 and 1989, U.S. Outward FDI Production Share, 1977 and 1994 , and U.S. Inward FDI Production Share, 1994 (BEA Industries)

\begin{tabular}{|c|c|c|c|c|c|c|c|c|}
\hline \multirow[t]{2}{*}{ No. } & \multirow[t]{2}{*}{ BEA Industries } & \multicolumn{2}{|c|}{$\begin{array}{c}\text { U.S. Export Comparative } \\
\text { Advantage Relative to } \\
\text { World }\end{array}$} & \multicolumn{3}{|c|}{$\begin{array}{c}\text { Outward FDI Production } \\
\text { Share }\end{array}$} & \multirow{2}{*}{$\begin{array}{c}\begin{array}{c}\text { Inward FDI } \\
\text { Production } \\
\text { Share }\end{array} \\
1994\end{array}$} & \multirow{2}{*}{$\begin{array}{c}\begin{array}{c}\text { Outward / } \\
\text { Inward FDI } \\
\text { Production Shar }\end{array} \\
1994\end{array}$} \\
\hline & & 1970 & 1989 & 1977 & 1994 & $1994 / 1977$ & & \\
\hline 1 & Grain Mill and Bakery Products & 1.61 & 1.46 & 0.55 & 1.21 & 2.20 & NA & NA \\
\hline 2 & Beverages & 0.20 & 0.29 & 0.69 & 2.21 & 3.20 & 0.71 & 3.11 \\
\hline 3 & Tobacco Products & 1.91 & 3.23 & 2.37 & 3.12 & 1.32 & NA & NA \\
\hline 4 & Other Food and Kindred Products & 0.68 & 0.74 & 2.54 & 2.71 & 1.07 & $3.21^{\mathrm{a}}$ & 1.22 \\
\hline 5 & Apparel and Other Textile Products & 0.31 & 0.28 & 0.69 & 0.64 & 0.93 & 1.23 & 0.52 \\
\hline 6 & Leather and Leather Products & 0.14 & 0.23 & NA & NA & NA & NA & NA \\
\hline 7 & Pulp, Paper, and Board Mills & 0.92 & 0.93 & 144 & 156 & 108 & 130 & 120 \\
\hline 8 & Other Paper and Allied Products & 0.85 & 1.24 & & & & & \\
\hline 9 & Printing and Publishing & 1.30 & 1.61 & 0.41 & 0.53 & 1.29 & 2.73 & 0.19 \\
\hline 10 & Drugs & 0.94 & 0.99 & 2.21 & 3.52 & 1.59 & 4.81 & 0.73 \\
\hline 11 & Soaps, Cleaners, and Toilet Goods & 0.85 & 0.68 & 1.60 & 2.03 & 1.27 & 1.55 & 1.31 \\
\hline 12 & Agricultural Chemicals & 0.99 & 1.75 & NA & 0.25 & NA & NA & NA \\
\hline 13 & Industrial Chemicals and Synthetics & 1.21 & 1.19 & 3.51 & 3.42 & 0.97 & 7.99 & 0.43 \\
\hline 14 & Other Chemicals & 0.92 & 0.91 & 0.38 & 0.93 & 2.45 & $1.15^{\mathrm{b}}$ & 1.03 \\
\hline 15 & Rubber Products & 0.66 & 0.71 & 1.60 & 1.15 & 0.72 & 1.50 & 0.77 \\
\hline 16 & Miscellaneous Plastic Products & 0.87 & 0.88 & 0.18 & 0.89 & 4.94 & 0.71 & 1.25 \\
\hline 17 & Primary Metal Industries, Ferrous & 0.61 & 0.28 & 0.52 & 0.13 & 0.25 & 2.02 & 0.06 \\
\hline 18 & Primary Metal Industries, Nonferrous & 0.53 & 0.80 & 1.04 & 0.48 & 0.46 & 1.05 & 0.46 \\
\hline 19 & Fabricated Metal Products & 1.24 & 1.02 & 1.43 & 1.39 & 0.97 & 2.17 & 0.64 \\
\hline 20 & Farm and Garden Machinery & 1.18 & 1.48 & 0.37 & 0.23 & 0.62 & NA & NA \\
\hline 21 & $\begin{array}{l}\text { Construction, Mining, and Materials } \\
\text { Handling Machinery }\end{array}$ & 1.99 & 1.40 & 1.31 & 0.78 & 0.60 & NA & NA \\
\hline 22 & Computer and Office Equipment & 2.29 & 1.82 & 7.85 & 4.03 & 0.51 & 0.52 & 7.75 \\
\hline 23 & Other Nonelectric Machinery & 1.24 & 1.16 & 1.68 & 1.77 & 1.05 & $3.60^{\mathrm{c}}$ & 0.77 \\
\hline 24 & Household Appliances & 0.55 & 0.58 & 0.62 & 0.43 & 0.69 & NA & NA \\
\hline 25 & $\begin{array}{l}\text { Household Audio and Video, and } \\
\text { Communications, Equipment }\end{array}$ & 0.86 & 0.95 & 0.48 & 0.95 & 1.98 & 1.80 & 0.53 \\
\hline 26 & Electronic Components and Accessories & 1.95 & 1.57 & 0.42 & 2.55 & 6.07 & 0.96 & 2.66 \\
\hline 27 & Other Electrical Machinery & 1.08 & 1.09 & 1.84 & 0.99 & 0.54 & $3.16^{\mathrm{d}}$ & 0.45 \\
\hline 28 & Motor Vehicles and Equipment & 1.14 & 0.92 & 9.02 & 8.52 & 0.94 & 1.81 & 4.71 \\
\hline 29 & Other Transportation Equipment & 1.96 & 2.10 & 1.67 & 0.37 & 0.22 & 0.57 & 0.65 \\
\hline 30 & Lumber, Wood, Furniture etc. & 0.63 & 0.96 & 0.45 & 0.58 & 1.29 & 0.49 & 1.18 \\
\hline 31 & Glass Products & 0.87 & 0.77 & 0.37 & 0.28 & 0.76 & 2.17 & 0.33 \\
\hline 32 & $\begin{array}{l}\text { Stone, Clay, concrete, Gypsum and Other } \\
\text { Nonmetallic Mineral Products }\end{array}$ & 0.55 & 0.44 & 0.66 & 0.44 & 0.67 & & \\
\hline 33 & Instruments and Apparatus & 1.47 & 1.46 & 2.04 & 2.31 & 1.13 & 1.94 & 1.19 \\
\hline 34 & Other Manufacturing & 0.55 & 0.52 & 0.32 & 0.45 & 1.41 & 1.02 & 0.44 \\
\hline
\end{tabular}

\footnotetext{
${ }^{\text {a }}$ Grain Mill and Bakery Products are included.

${ }^{\mathrm{b}}$ Agricultural Chemicals are included.

${ }^{c}$ Farm and Garden Machinery, and Construction, Mining, and Materials Handling Machinery are included.

${ }^{\mathrm{d}}$ Household Appliances are included.
} 
Table 17. Comparative Advantage of US Nonbank MNCs and Their Parents, 1989 and 1994

\begin{tabular}{|c|c|c|c|c|c|}
\hline \multirow[t]{2}{*}{ BEA } & \multirow[t]{2}{*}{ Manufacturing } & \multicolumn{2}{|c|}{1989} & \multicolumn{2}{|c|}{1994} \\
\hline & & Parent & MNC & Parent & MNC \\
\hline 1 & Grain Mill and Bakery Products & 3.04 & 2.37 & 2.79 & 2.15 \\
\hline 2 & Beverages & 0.43 & 0.89 & 2.77 & 2.26 \\
\hline 3 & Tobacco Products & 3.08 & 2.76 & 1.56 & 2.16 \\
\hline 4 & Other Food and Kindred Products & 0.34 & 0.42 & 1.06 & 0.85 \\
\hline 5 & Apparel and Other Textile Products & 0.07 & 0.11 & 0.10 & 0.13 \\
\hline 6 & Leather and Leather Products & 0.00 & 0.00 & 0.00 & 0.00 \\
\hline 7 & Pulp, Paper, and Board Mills & 1.01 & 0.97 & 1.47 & 1.03 \\
\hline 8 & Other Paper and Allied Products & & & & \\
\hline 9 & Printing and Publishing & 0.48 & 0.49 & 0.60 & 0.69 \\
\hline 10 & Drugs & 3.99 & 3.19 & 3.72 & 3.50 \\
\hline 11 & Soaps, Cleaners, and Toilet Goods & 1.97 & 2.04 & 1.45 & 2.11 \\
\hline 12 & Agricultural Chemicals & 1.17 & 0.76 & 0.57 & 0.58 \\
\hline 13 & Industrial Chemicals and Synthetics & 1.10 & 1.25 & 1.03 & 1.07 \\
\hline 14 & Other Chemicals & 0.59 & 0.81 & 0.79 & 0.82 \\
\hline 15 & Rubber Products & 0.41 & 0.95 & 0.83 & 1.13 \\
\hline 16 & Miscellaneous Plastic Products & 0.44 & 0.67 & 0.65 & 1.29 \\
\hline 17 & Primary Metal Industries, Ferrous & 0.12 & 0.09 & 0.15 & 0.09 \\
\hline 18 & Primary Metal Industries, Nonferrous & 0.63 & 0.45 & 0.60 & 0.43 \\
\hline 19 & Fabricated Metal Products & 0.79 & 0.91 & 0.66 & 0.75 \\
\hline 20 & Farm and Garden Machinery & 2.79 & 3.86 & 2.65 & 2.64 \\
\hline 21 & $\begin{array}{l}\text { Construction, Mining, and Materials } \\
\text { Handling Machinery }\end{array}$ & 1.14 & 1.14 & 1.64 & 1.25 \\
\hline 22 & Computer and Office Equipment & 2.50 & 2.98 & 1.88 & 2.86 \\
\hline 23 & Other Nonelectric Machinery & 0.38 & 0.41 & 0.52 & 0.44 \\
\hline 24 & Household Appliances & 0.53 & 0.61 & 0.76 & 1.00 \\
\hline 25 & $\begin{array}{l}\text { Household Audio and Video, and } \\
\text { Communications, Equipment }\end{array}$ & 1.30 & 0.77 & 0.28 & 0.24 \\
\hline 26 & Electronic Components and Accessories & 1.36 & 1.90 & 3.53 & 2.89 \\
\hline 27 & Other Electrical Machinery & 0.52 & 0.47 & 0.95 & 0.71 \\
\hline 28 & Motor Vehicles and Equipment & 1.08 & 1.67 & 1.14 & 1.73 \\
\hline 29 & Other Transportation Equipment & 3.95 & 2.05 & 2.38 & 1.26 \\
\hline 30 & Lumber, Wood, Furniture etc. & 0.52 & 0.36 & 0.30 & 0.35 \\
\hline 31 & Glass Products & 0.72 & 0.88 & 0.85 & 0.86 \\
\hline 32 & $\begin{array}{l}\text { Stone, Clay, concrete, Gypsum and Other } \\
\text { Nonmetallic Mineral Products }\end{array}$ & 0.41 & 0.43 & 0.24 & 0.35 \\
\hline 33 & Instruments and Apparatus & 1.68 & 1.40 & 1.52 & 1.24 \\
\hline 34 & Other Manufacturing & 0.18 & 0.17 & 0.16 & 0.21 \\
\hline
\end{tabular}


Table 18. Equations Relating US and US MNC Export Comparative Advantage to Industry Distribution of US Production Abroad and Foreign Production in the US

\begin{tabular}{|c|c|c|c|c|c|c|c|c|}
\hline \multirow[t]{2}{*}{ Equation No. ${ }^{a}$} & \multirow[t]{2}{*}{ Dependent Variable } & \multirow[t]{2}{*}{ Date } & \multicolumn{3}{|c|}{ Independent Variable } & \multirow[t]{2}{*}{ Adj. R-sq. } & \multirow[t]{2}{*}{ Prob. $>$ F } & \multirow[t]{2}{*}{ No. of Obs } \\
\hline & & & Name & Date & Coefficient & & & \\
\hline $18-1$ & Outward Industry VA Share & 1977 & US Exp. Comp. Adv. & 1970 & $\begin{array}{c}1.808 \\
(2.449)^{\mathrm{b}}\end{array}$ & 0.167 & 0.022 & 26 \\
\hline $18-2$ & $"$ & 1982 & $"$ & 1977 & $\begin{array}{c}1.022 \\
(3.386)\end{array}$ & 0.287 & 0.002 & 27 \\
\hline $18-3$ & $"$ & 1989 & $"$ & 1982 & $\begin{array}{c}0.024 \\
(2.611)\end{array}$ & 0.189 & 0.015 & 26 \\
\hline $18-4$ & $"$ & 1994 & $"$ & 1989 & $\begin{array}{c}0.640 \\
(1.146)\end{array}$ & 0.012 & 0.263 & 27 \\
\hline $18-5$ & Inward Industry VA Share & 1994 & $"$ & 1989 & $\begin{array}{c}0.124 \\
(0.169)\end{array}$ & -0.042 & 0.867 & 25 \\
\hline $18-6$ & Outward / Inward VA Share & 1994 & $"$ & 1970 & $\begin{array}{c}1.559 \\
(2.575)\end{array}$ & 0.190 & 0.017 & 25 \\
\hline $18-7$ & $"$ & 1994 & $"$ & 1989 & $\begin{array}{c}1.083 \\
(1.504)\end{array}$ & 0.050 & 0.146 & 25 \\
\hline $18-8$ & Outward Industry VA Share & 1994 & US MNC Exp. Comp. Adv. & 1989 & $\begin{array}{c}1.092 \\
(3.101)\end{array}$ & 0.249 & 0.005 & 27 \\
\hline $18-9$ & Inward Industry VA Share & 1994 & $"$ & 1989 & $\begin{array}{c}0.201 \\
(0.492)\end{array}$ & -0.033 & 0.628 & 25 \\
\hline $18-10$ & Outward / Inward VA Share & 1994 & $"$ & 1989 & $\begin{array}{c}1.152 \\
(3.297)\end{array}$ & 0.291 & 0.003 & 25 \\
\hline
\end{tabular}

\footnotetext{
${ }^{\text {a }}$ Constant term omitted

${ }^{\mathrm{b}} \mathrm{t}$-statistics in parentheses
} 
